Historic, Archive Document

Do not assume content reflects current scientific knowledge, policies, or practices. 

United States

(G) Department of Agriculture

aSD11.A48

Report INT-GTR-331

33/ December 1995

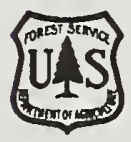

Major Douglas-fir Habitat Types of Central Idaho: A Summary of Succession and Management

Robert Steele

Kathleen Geier-Hayes

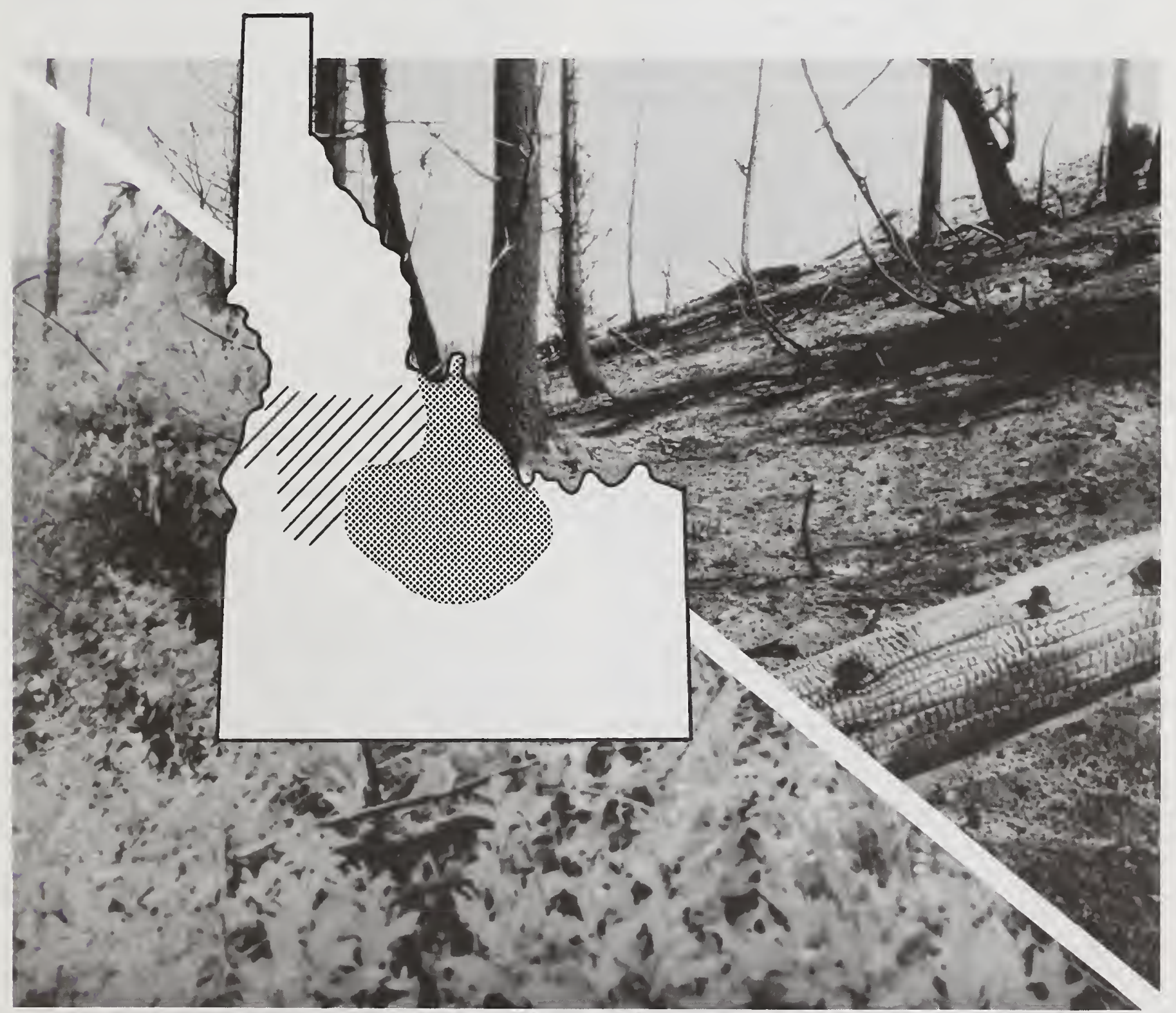




\section{The Authors}

Robert Steele (retired) was a Research Forester assigned to the Rocky Mountain Douglas-fir and Ponderosa Pine Ecosystems Research Work Unit in Boise, ID. He joined the Intermountain Research Station in 1972 and worked there until his retirement in 1994. While at the Intermountain Research Station, he concentrated on development of forest habitat type classification and on classification and management of successional forest communities. He earned a B.S. degree in forest management and an M.S. degree in forest ecology at the University of Idaho.

Kathleen Geier-Hayes is a Research Forester in the Rocky Mountain Douglas-fir and Ponderosa Pine Ecosystems Research Work Unit. She worked part time on the classification and management of successional forest communities since the project began in 1979 and joined the Intermountain Research Station full time in 1986. She earned a B.S. degree in biology at Boise State University and an M.S. degree in forest science at the University of Idaho.

\section{Research Summary}

This report summarizes the important successional features of seven central Idaho Douglas-fir habitat types. The habitat types and phases are geographically grouped into west-central and east-central Idaho to differentiate site potential based on ponderosa pine presence. Fire history and fire groups of the various habitat types are described to provide a historical perspective for management activities. Major seral tree, shrub, and herbaceous species are discussed, including a species' role in the habitat type and its response to different disturbances. Management scenarios for creating or maintaining various plant communities are described. Discussions about natural and planted conifer regeneration and the effect of management activities on establishment, survival, and growth are included.

\section{Acknowledgments}

Much of the funding for this study was provided by the Intermountain Region of the Forest Service, U.S. Department of Agriculture, through a memorandum of understanding with the Intermountain Research Station.

Boise, Payette, and Salmon National Forest staff provided logistical support and helpful information during field sampling. Phil Straub, retired (Boise National Forest), Glenn Jacobsen (Payette National Forest), and Doug Basford (Salmon National Forest) provided support and advice during the study's development. Bob Keane, Pete Stickney, Steve Arno (Intermountain Research Station), and Ron Hamilton (Payette National Forest) offered many helpful suggestions and insights.

The use of trade or firm names in this publication is for reader information and does not imply endorsement by the U.S. Department of Agriculture of any product or service. 


\title{
Major Douglas-fir Habitat Types of Central Idaho: A Summary of Succession and Management
}

\author{
Robert Steele \\ Kathleen Geier-Hayes
}

\section{Introduction}

Growing interest in managing forests as ecosystems rather than emphasizing individual, and often conflicting, resource values has created a need for better understanding of ecosystem processes. In response to this need, we have developed succession classifications for several important habitat types and explored the interactions of various site treatments, plant species responses, and related resource values. This report summarizes these successional studies of the major Douglas-fir (Pseudotsuga menziesii) habitat types in central Idaho (Steele and Geier-Hayes 1987, 1989a,b, 1993, 1994).

Forest succession is the replacement of species in some kind of order (Oosting 1956) and is expressed as changes in species composition and cover over time. Understanding succession is essential to managing forests on an ecological basis. Successional changes are due to the competitive abilities of plant species, which are determined by such attributes as tolerance for shade and allelopathic chemicals, reproductive strategies, and longevity. The relative competitive ability of each plant species instills order in the successional process and makes successional trends predictable. However, the effects of fire, insects, disease, and abnormal weather often alter the progress and direction of these trends.

In spite of recurring disruptions, the predictability of successional trends is one of the most powerful tools for managing forest ecosystems. It influences the expectation of useful timber, forage, wildlife, and water resources as well as vulnerability to destructive insect, disease, and wildfire events. When coupled with known responses to management treatments, predictability provides a means for assessing the longterm impacts of management alternatives. But most successional changes occur slowly, often over decades, and are so difficult for people to recognize that they have been referred to as "the invisible present" (Magnuson 1990).

Forest successions are initiated by disturbance, and in the Northern Rocky Mountains the primary disturbance for the past several centuries has been fire (Wellner 1970). Before settlement by EuroAmericans, these fires occurred with different periodicities in different ecosystems (Martin 1982). Disturbance frequency determined the length of successional trend and the historical range of plant communities in a particular ecosystem. In general, ecosystems with frequent disturbances had continually interrupted successions and exhibited only a narrow range of plant communities. An extreme example would be a 5-year average fire return interval; this would prevent nearly all succession and maintain a single plant community as the norm. In central Idaho, ponderosa pine/pinegrass (Pinus ponderosa/Calamagrostis rubescens) communities were maintained by frequent underburns that prevented succession to Douglas-fir. Conversely, ecosystems with infrequent disturbances experienced more successional stages. For instance, some forest sites on the western slope of the Cascade Range have not burned for over 400 years (Morrison and Swanson 1990). During this period, these sites may have experienced a broad range of plant communities.

The type and frequency of disturbance that occurred before settlement by Euro-Americans provide a management guide for maintaining sites within their historical range of plant communities (Morgan and others in press). This helps ensure a functional forest ecosystem that can recover from future disturbance without loss of productivity. For example, the historical intensity and frequency of burning in our ponderosa pine forests resulted from both lightning and Native American ignitions. This disturbance pattern continued for centuries, evolving into a combination of natural and long-standing cultural practices that maintained a sustainable ecosystem.

This report summarizes important successional aspects of seven habitat types in central Idaho, all in the Douglas-fir series (table 1). These habitat types are quite similar, yet the range of plant communities can be quite different. Currently, humancaused disturbances such as machine scarification and clearcutting on the driest of these habitat types have produced plant communities that are outside the historical range for these sites. Significantly, 
Table 1-Habitat types and phases summarized in this report showing elevational ranges.

\begin{tabular}{|c|c|c|}
\hline & Abbreviation & Elevational range \\
\hline West-central Idaho & & - - - - Feet - . - \\
\hline $\begin{array}{l}\text { Pseudotsuga menziesii/Carex geyeri h.t., } \\
\text { Pinus ponderosa phase }\end{array}$ & $\begin{array}{l}\text { PSME/CAGE h.t., } \\
\text { PIPO phase }\end{array}$ & 4,000 to 6,500 \\
\hline $\begin{array}{l}\text { Pseudotsuga menziesii/Calamagrostis rubescens h.t., } \\
\text { Pinus ponderosa phase }\end{array}$ & $\begin{array}{l}\text { PSME/CARU h.t., } \\
\text { PIPO phase }\end{array}$ & 3,500 to 6,500 \\
\hline $\begin{array}{l}\text { Pseudotsuga menziesii/Berberis repens h.t., } \\
\text { Berberis repens phase }\end{array}$ & $\begin{array}{l}\text { PSME/BERE h.t., } \\
\text { BERE phase }\end{array}$ & 4,300 to 6,500 \\
\hline $\begin{array}{l}\text { Pseudotsuga menziesii/Spiraea betulifolia h.t., } \\
\text { Pinus ponderosa phase }\end{array}$ & $\begin{array}{l}\text { PSME/SPBE h.t., } \\
\text { PIPO phase }\end{array}$ & 3,300 to 6,600 \\
\hline $\begin{array}{l}\text { Pseudotsuga menziesii/Symphoricarpos albus h.t., } \\
\text { Pinus ponderosa phase }\end{array}$ & $\begin{array}{l}\text { PSME/SYAL h.t., } \\
\text { PIPO phase }\end{array}$ & 3,200 to 6,000 \\
\hline $\begin{array}{l}\text { Pseudotsuga menziesii/Physocarpus malvaceus h.t., } \\
\text { Pinus ponderosa phase }\end{array}$ & $\begin{array}{l}\text { PSME/PHMA h.t., } \\
\text { PIPO phase }\end{array}$ & 3,100 to 6,400 \\
\hline $\begin{array}{l}\text { Pseudotsuga menziesii/Acer glabrum h.t., } \\
\text { Acer glabrum phase }\end{array}$ & $\begin{array}{l}\text { PSME/ACGL h.t., } \\
\text { ACGL phase }\end{array}$ & 4,500 to 6,800 \\
\hline \multicolumn{3}{|l|}{ East-central Idaho } \\
\hline $\begin{array}{l}\text { Pseudotsuga menziesii/Carex geyeri h.t., } \\
\text { Carex geyeri phase }\end{array}$ & $\begin{array}{l}\text { PSME/CAGE h.t., } \\
\text { CAGE phase }\end{array}$ & 6,300 to 7,800 \\
\hline $\begin{array}{l}\text { Pseudotsuga menziesii/Calamagrostis rubescens h.t., } \\
\text { Calamagrostis rubescens phase }\end{array}$ & $\begin{array}{l}\text { PSME/CARU h.t., } \\
\text { CARU phase }\end{array}$ & 4,700 to 7,900 \\
\hline $\begin{array}{l}\text { Pseudotsuga menziesii/Berberis repens h.t., } \\
\text { Berberis repens phase }\end{array}$ & $\begin{array}{l}\text { PSME/BERE h.t., } \\
\text { BERE phase }\end{array}$ & 5,700 to 7,800 \\
\hline $\begin{array}{l}\text { Pseudotsuga menziesii/Spiraea betulifolia h.t., } \\
\text { Calamagrostis rubescens phase }\end{array}$ & $\begin{array}{l}\text { PSME/SPBE h.t., } \\
\text { CARU phase }\end{array}$ & 6,000 to 7,900 \\
\hline $\begin{array}{l}\text { Pseudotsuga menziesii/Symphoricarpos albus h.t., } \\
\text { Symphoricarpos albus phase }\end{array}$ & $\begin{array}{l}\text { PSME/SYAL h.t., } \\
\text { SYAL phase }\end{array}$ & 5,200 to 7,300 \\
\hline $\begin{array}{l}\text { Pseudotsuga menziesii/Physocarpus malvaceus h.t., } \\
\text { Pseudotsuga menziesii phase }\end{array}$ & $\begin{array}{l}\text { PSME/PHMA h.t., } \\
\text { PSME phase }\end{array}$ & 5,000 to 7,100 \\
\hline $\begin{array}{l}\text { Pseudotsuga menziesii/Acer glabrum h.t., } \\
\text { Symphoricarpus oreophilus phase }\end{array}$ & $\begin{array}{l}\text { PSME/ACGL h.t., } \\
\text { SYOR phase }\end{array}$ & 6,500 to 8,000 \\
\hline
\end{tabular}

some major management problems such as high pocket gopher populations and poor tree seedling growth are often associated with these "abnormal" plant communities.

In this report, the habitat types and phases are grouped geographically into west-central and eastcentral Idaho. The potential of sites in west-central Idaho to naturally support ponderosa pine differentiates many of the westside Douglas-fir habitat types and phases from their eastside counterparts. In west-central Idaho, factors that correlate with ponderosa pine occurrence are lower elevations and a stronger maritime climate. East-central Idaho has higher elevations and a more continental climate.

The west-central area is drained by the Weiser, Little Salmon, Boise, and Payette Rivers; the South Fork, Middle Fork, and North Fork of the Salmon River, and the main Salmon River from the North Fork to the Little Salmon (fig. 1). East-central Idaho is drained by the remainder of the Salmon River drainage upstream from the North Fork, the Big Wood, the Big Lost, and Little Lost Rivers, and the Birch
Creek (fig. 1). Geologically, this delineation largely separates the Columbia River basalts and Idaho Batholith granitics in the west from the Wood River sedimentaries, Challis volcanics, and other assorted formations to the east. A more complete description of the study area is provided in Steele and others (1981).

\section{Fire History and Behavior}

\section{West-Central Idaho}

In west-central Idaho, most Douglas-fir habitat types in this study fall within Crane and Fischer's (1986) fire group three (table 2). Possible exceptions are PSME/BERE and PSME/ACGL at their upper elevational limits, and PSME/PHMA on steep north slopes. In these cooler or moister situations, ponderosa pine is only a minor component of the stand or is absent. Consequently, these sites are in fire group five. 


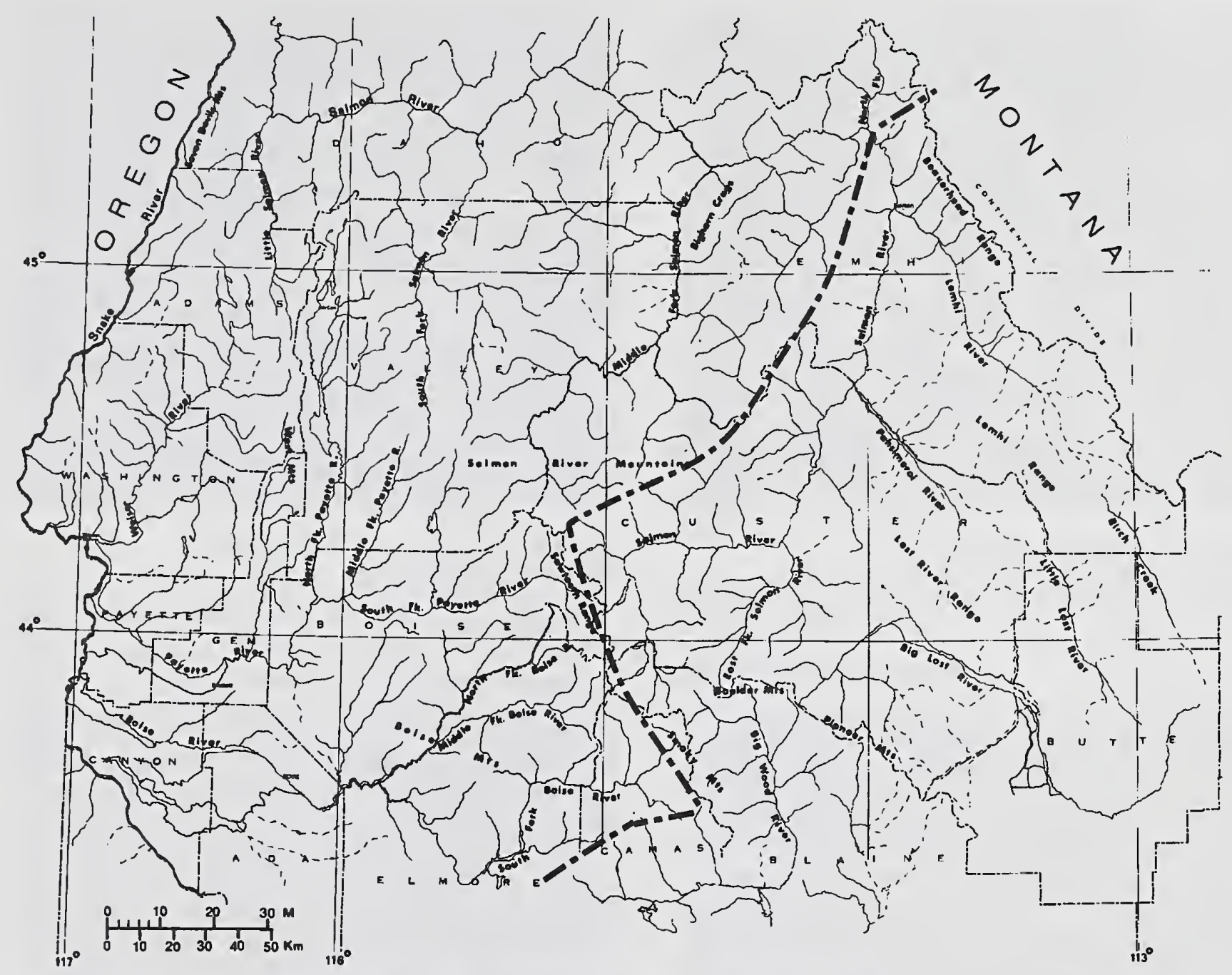

Figure 1-The study area showing major river drainages and delineations (dashed line) of west-central and east-central Idaho.

Table 2-Fire groups ${ }^{1}$ for major Douglas-fir habitat types in west-central and east-central Idaho.

\begin{tabular}{cl}
\hline Fire group & Habitat type and phase \\
\hline 3 & PSME/CAGE - PIPO \\
& PSME/CARU - PIPO \\
& PSME/BERE - SYOR \\
& PSME/BERE - CAGE \\
& PSME/SPBE - PIPO \\
& PSME/SYAL - PIPO \\
& PSME/PHMA - PIPO \\
& PSME/CAGE - SYOR \\
& PSME/CAGE - CAGE \\
& PSME/CARU - CARU \\
& PSME/SPBE - CARU \\
& PSME/SPBE - SPBE \\
& PSME/SYAL - SYAL \\
& PSME/ACGL - SYOR \\
& PSME/BERE - BERE \\
& PSME/PHMA - PSME \\
& PSME/ACGL - ACGL \\
\hline
\end{tabular}

${ }^{1}$ Crane and Fischer 1986.

${ }^{2}$ Fire group 5 at upper elevational limits (cooler and moister) where ponderosa pine is absent.
Natural fire frequency on fire group three sites is thought to be about 10 to 20 years (Barrett 1984; Steele and others 1986) but may range from 3 to 30 years (Arno and Peterson 1983). At such fire intervals fuel loadings remain low, about 10 tons/acre $\left(2.24 \mathrm{~kg} / \mathrm{m}^{2}\right)$ (Crane and Fischer 1986), and most fires are underburns. Stands consist mainly of widely spaced ponderosa pine. Where thickets or clusters of trees develop, fires either thin the clusters or destroy the entire group. Small Douglas-fir trees are more vulnerable to fire than ponderosa pine and rarely survive frequent burning. As a result, there is little or no development of understory ladder fuels that would promote a stand-destroying fire.

High fire frequency maintains a narrow range of plant communities. Most stands remain dominated by ponderosa pine with an open shelterwood canopy that is conducive to pine regeneration (fig. 2). The frequent fires create suitable pine seedbeds that 


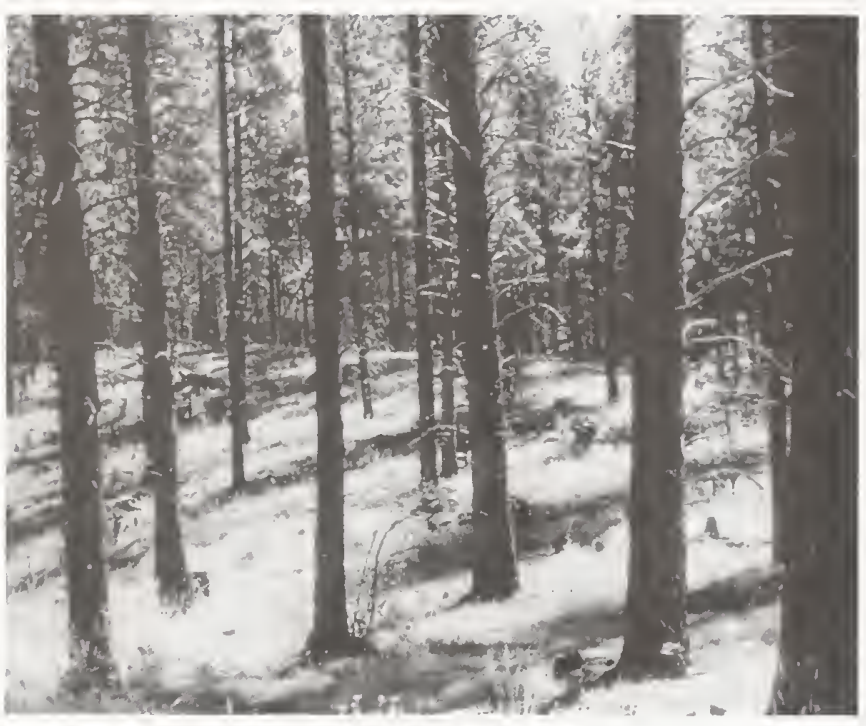

Figure 2-A Douglas-fir/pinegrass habitat type in west-central Idaho maintained in an open ponderosa pine community by thinning and underburning.

sometimes coincide with pine cone crops. In this manner, pine recruitment compensates for normal mortality. When recruitment exceeds mortality and stand basal area exceeds sustainable levels, bark beetles (Dendroctonus spp.) reduce the number of live trees (Cochran and Barrett 1993), creating snags and fallen logs.

Since the early 1900 's, fire control has changed this pattern; stands of widely spaced ponderosa pine have accumulated dense understories of Douglas-fir and thick layers of duff, creating highly flammable conditions. Subsequent crown fires have killed the large ponderosa pines that survived several centuries of underburns. Where thick duff has accumulated, even low intensity underburns can generate enough heat to kill the cambium at the base of large ponderosa pines (Ryan and Frandsen 1991).

The fire group five sites and the cool moist portions of the PSME/PHMA and PSME/ACGL habitat types occur on northerly aspects that are cooler and more moist (fig. 3). These sites are often contiguous with group three sites on the warmer, drier slopes. As a result many cool, moist sites in the Douglas-fir zone are exposed to the same 10- to 20-year fire return interval, but the burning conditions are more variable. In some years, these northerly aspects are too moist to support a thorough underburn. The frequency of effective burning is decreased; fuel ladders develop, and duff layers thicken. In other years these group five sites are quite dry at time of ignition and the stand experiences a crown fire. There are also many

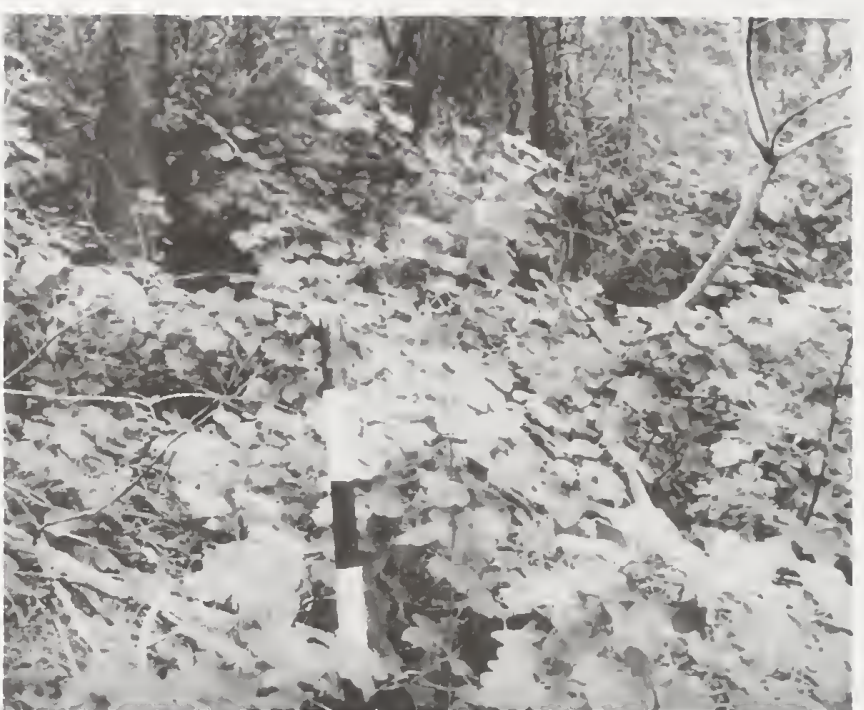

Figure 3-A Douglas-fir/ninebark habitat type, ponderosa pine phase.

intermediate situations where the stand experiences an underburn and partial crown fire. Because of the greater variability in fire behavior, a wider variety of seral communities occurs on these sites. Stand-destroying fires result in tall shrubfields that sometimes resist fire for decades, but also promote development of shade tolerant but more flammable Douglas-fir. This situation can eventually lead to another standdestroying fire. Thorough underburns every 10 to 20 years would favor ponderosa pine, but rarely is there enough pine in these stands to indicate that frequent effective underburning was the norm. In most cases, the pine is widely scattered or in small groups throughout a stand of Douglas-fir. Most fires created small openings in the stand while lightly underburning or skipping other areas. In this manner, a mosaic of plant communities was maintained that fostered a mosaic of burning conditions. Since the advent of fire control, many of these stands have accumulated more uniform Douglas-fir understories, making them vulnerable to more extensive stand-destroying wildfire.

\section{East-Central Idaho}

In east-central Idaho, most Douglas-fir habitat types in this study fall within fire group four except PSME/BERE and PSME/PHMA, which are in group five (Crane and Fischer 1986). Natural fire frequency on group four sites is poorly documented in eastcentral Idaho but lightning-caused fires are known to be infrequent. On similar sites in southwestern 
Table 3-Major tree species of west-central Idaho and their role in major Douglas-fir habitat types.

\begin{tabular}{|c|c|c|c|c|c|c|c|}
\hline \multirow[b]{2}{*}{$\begin{array}{c}\text { Tree } \\
\text { species }\end{array}$} & \multicolumn{7}{|c|}{ PSME habitat type-phase } \\
\hline & $\begin{array}{l}\text { CAGE- } \\
\text { PIPO }\end{array}$ & $\begin{array}{l}\text { CARU- } \\
\text { PIPO }\end{array}$ & $\begin{array}{l}\text { BERE- } \\
\text { BERE }\end{array}$ & $\begin{array}{l}\text { SPBE- } \\
\text { PIPO }\end{array}$ & $\begin{array}{l}\text { SYAL- } \\
\text { PIPO }\end{array}$ & $\begin{array}{l}\text { PHMA- } \\
\text { PIPO }\end{array}$ & $\begin{array}{l}\text { ACGL. } \\
\text { ACGL }\end{array}$ \\
\hline Abies grandis & - & - & - & $a^{1}$ & a & a & - \\
\hline Abies lasiocarpa & - & - & - & a & - & - & - \\
\hline Juniperus scopulorum & - & - & - & - & - & - & - \\
\hline Picea engelmannii & - & - & - & a & - & - & - \\
\hline Pinus albicaulis & - & - & - & - & - & - & - \\
\hline Pinus contorta & (S) & (S) & (S) & (s) & (s) & - & - \\
\hline Pinus flexilis & - & - & - & - & - & - & - \\
\hline Pinus ponderosa & $S$ & $S$ & (S) & $S$ & $S$ & $S$ & (S) \\
\hline Populus tremuloides & (S) & (S) & (S) & (S) & (S) & (S) & (S) \\
\hline Pseudotsuga menziesii & c & C & C & c & C & C & C \\
\hline
\end{tabular}

\footnotetext{
${ }^{1} S=$ seral; $a=$ accidental; $C=$ climax; $-=$ does not occur; ()$=$ occurs in only part of the habitat type; upper case = major species
} occurrence; lower case = minor species occurrence.

Montana, Arno and Gruell (1983) estimated an average fire return interval of 41 years. The longer firefree periods are evidenced by dense pole-size stands of Douglas-fir and lodgepole pine (Pinus contorta) and severe infection by dwarf mistletoe (Arceuthobium spp.). In some areas, however, fire-scarred trees can be found, indicating that low intensity underburns occurred between stand-destroying fires. These low intensity fires tended to thin the stands and reduce the number of mistletoe-infected trees. But emulating natural underburns with prescribed fire in eastcentral Idaho may damage the stands because Douglasfir and lodgepole pine are more susceptible to fire damage and mortality than the ponderosa pine of west-central Idaho. Mechanical thinning and site preparation followed by burning of fuel concentrations appear to be a logical alternative.

\section{Tree Layer}

\section{Major Seral Species}

The composition of seral tree layers is quite simple. Quaking aspen (Populus tremuloides), lodgepole pine, and ponderosa pine are the only major seral species occurring in these habitat types (tables 3,4 ). By definition, Douglas-fir is climax in all the habitat types.

Quaking Aspen-Quaking aspen occurs sporadically throughout all seven habitat types. Its occurrences appear related to certain soil conditions (possibly finer textures) created by landslides, loess deposits, and alluvium. Although highly shade intolerant, quaking aspen has an impressive ability to maintain its dominance in the presence of pine and Douglas-fir seed sources. Aspen leaf litter is allelopathic to some

Table 4-Major tree species of east-central Idaho and their role in major Douglas-fir habitat types.

\begin{tabular}{lcccccc}
\hline \multirow{2}{*}{$\begin{array}{c}\text { Tree } \\
\text { species }\end{array}$} & $\begin{array}{l}\text { CAGE- } \\
\text { CAGE }\end{array}$ & $\begin{array}{c}\text { CARU- } \\
\text { CARU }\end{array}$ & $\begin{array}{c}\text { SPBE- } \\
\text { CARU }\end{array}$ & $\begin{array}{c}\text { SYAL- } \\
\text { SYAL }\end{array}$ & $\begin{array}{c}\text { PHMA- } \\
\text { PSME }\end{array}$ & $\begin{array}{c}\text { ACGL- } \\
\text { SYOR }\end{array}$ \\
\hline Abies grandis & - & - & - & - & - & - \\
Abies lasiocarpa & $\mathrm{a}^{1}$ & - & - & $\mathrm{a}$ & - & - \\
Juniperus scopulorum & - & - & - & - & - & $(\mathrm{S})$ \\
Picea engelmannii & - & - & $\mathrm{a}$ & $\mathrm{a}$ & - & - \\
Pinus albicaulis & $\mathrm{a}$ & - & - & - & - & - \\
Pinus contorta & $(\mathrm{S})$ & $(\mathrm{S})$ & $(\mathrm{S})$ & $(\mathrm{S})$ & $(\mathrm{s})$ & - \\
Pinus flexilis & $\mathrm{a}$ & - & $\mathrm{a}$ & $(\mathrm{s})$ & $(\mathrm{s})$ & $(\mathrm{s})$ \\
Pinus ponderosa & - & - & - & - & - & - \\
Populus tremuloides & $(\mathrm{S})$ & $(\mathrm{S})$ & $(\mathrm{S})$ & $(\mathrm{S})$ & $\mathrm{a}$ & $(\mathrm{s})$ \\
Pseudotsuga menziesii & $\mathrm{C}$ & $\mathrm{C}$ & $\mathrm{C}$ & $\mathrm{C}$ & $\mathrm{C}$ & $\mathrm{C}$ \\
\hline
\end{tabular}

\footnotetext{
${ }^{1} S=$ seral; $a=$ accidental; $C=$ climax; $-=$ does not occur; ()$=$ occurs in only part of the habitat type; upper case = major species occurrence; lower case $=$ minor species occurrence.
} 


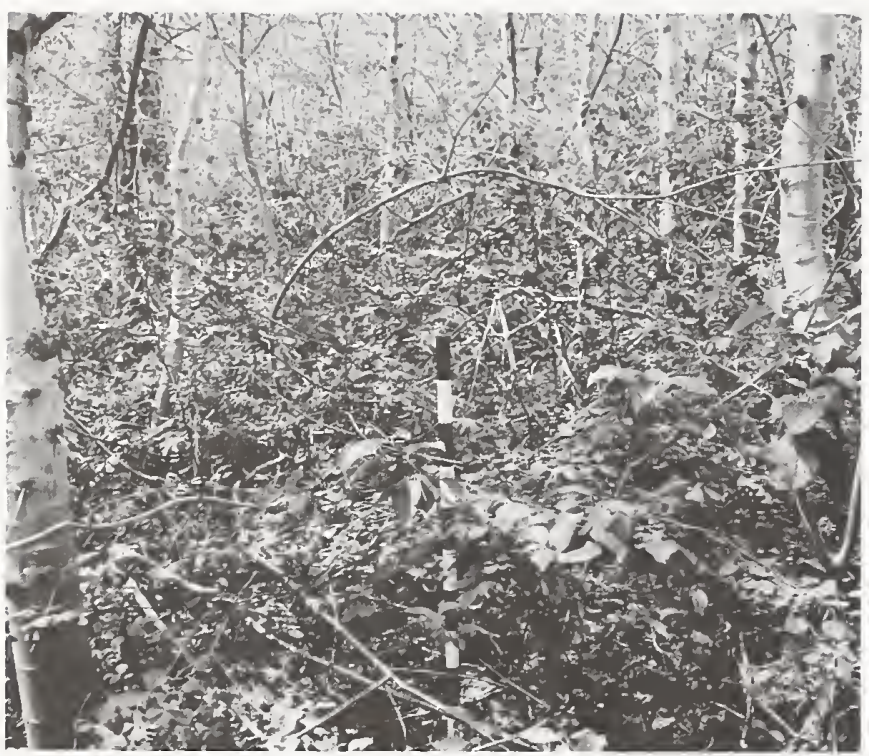

Figure 4-A quaking aspen community in the Douglas-fir/white spirea habitat type. The existing overstory dates back to a 1934 wildfire and most likely originated from rootsprouts.

plant species (Younger and others 1980) and may affect conifer germination and establishment. However, when conifer seedlings do become established, they easily outcompete aspen.

Aspen seedlings are found only rarely and are not a reliable means of reproduction. Quaking aspen reproduces mainly from root sprouts and forms large clones. Root sprouts usually occur near the clone periphery but may be absent if the clone is decadent or suppressed by conifers. Most clones will resprout if the shade is reduced and if the larger aspen stems are killed. Because quaking aspen sprouts are excellent deer and elk browse, regenerating aspen may be desirable in key big game areas. Historically, wildfire stimulated most of the root sprouting by burning through stands, killing above-ground portions of most aspen and conifers (Jones and DeByle 1985). The conifers died and the aspen resprouted (fig. 4). In addition to burning, current methods for stimulating sprouting include felling the larger trees or pushing them over with a bulldozer. This latter method leaves an unsightly condition, exposes soil to erosion, opens the site to noxious weeds, and can create compacted soils.

Lodgepole Pine-Lodgepole pine occurs in portions of five Douglas-fir habitat types and is absent in the PSME/PHMA and PSME/ACGL habitat types. Although more moist and slightly cooler than the other types, PSME/PHMA and PSME/ACGL sites invariably have good cold air drainage and do not occupy severe frostpockets. All seven habitat types tend to be warmer and slightly drier than is optimum for lodgepole pine so the pine generally occurs where nightly cold air accumulates and compensates for the warm, dry conditions. Therefore, lodgepole pine is able to occupy portions of these typically warm, dry habitat types and serve as an indicator of frost-prone areas. If the tree canopy is completely removed in these areas, the effects of frost during the growing season become evident. It is likely that the shrub cover will be sparse following any kind of treatment; sedges and grasses will dominate the undergrowth, and Douglas-fir seedlings will need thermal cover for proper development (fig. 5).

In most of central Idaho, lodgepole pine produces many cones that are nonserotinus. This feature enables lodgepole to reproduce whenever there is adequate seedbed and sunlight. Consequently, lodgepole stands often display several age classes. The classic, dense, even-age forests generated by standdestroying wildfire appear to be the origin of many lodgepole pine stands in central Idaho. But their initial uniform structure has been subsequently altered by creeping surface fires, bark beetles, and windstorms.

Lodgepole pine stands can resist mountain pine beetle attack if thinned to 80 to $100 \mathrm{ft}^{2} /$ acre (18.4 to $23 \mathrm{~m}^{2} / \mathrm{ha}$ ) of basal area (Amman and others 1988a; Cahill 1978; McGregor and others 1987). Apparently the low density alters stand microclimate such that the beetles cannot mount a successful attack (Amman and others 1988b, Bartos and Amman 1989; Schmitz and others 1989). These studies may encourage thinning to low densities in lodgepole stands because

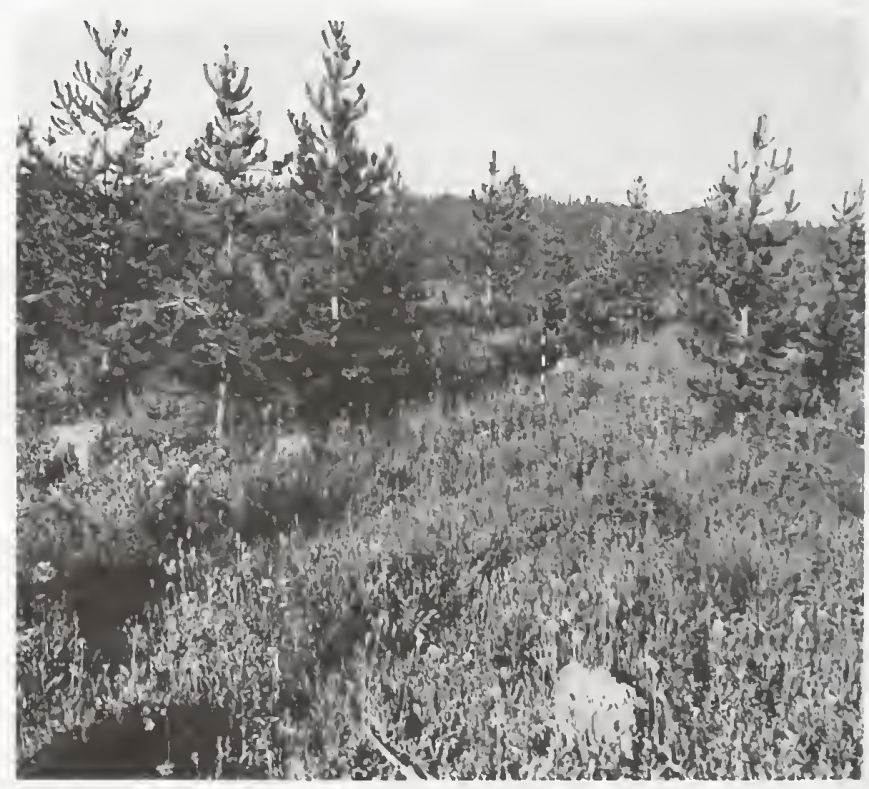

Figure 5-Lodgepole pine on a frosty site in the Douglas-fir/pinegrass habitat type. Early seral forbs and a variety of grasses and sedges dominate the understory. No shrubs occur here. 
regeneration is easily achieved and the public prefers partial cutting over clearcutting. But if dense stands are thinned to these levels, damage from wind must be considered. Open-grown lodgepole pine also may have less commercial value. Nevertheless, both thinning with underburning and clearcutting with broadcast burning fall within the historical range of variation for lodgepole stands on these dry Douglas-fir habitat types.

Ponderosa Pine-In west-central Idaho, ponderosa pine is the most common seral species in the seven habitat types; it serves as the phase indicator in five of the seven habitat types. Two habitat types, PSME/BERE and PSME/ACGL, occupy cooler sites and higher elevations than the other types. Because ponderosa pine requires warmer temperatures and a longer growing season than associated tree species, it does not extend into the cooler extremes of these types. By definition, ponderosa pine does not occur in the east-central Idaho phases.

Ponderosa pine is a fire-maintained species on habitats where it is seral to Douglas-fir and its success is strongly favored by frequent surface fires. On large trees, the lower branches are usually missing due to fire scorch. Past fire intensity can be estimated by height of the lowermost live branches. On steep terrain, the lowermost live branches are often notably higher on the uphill side of the bole where they are closer to the heat source. In these situations, management scenarios for ponderosa pine, on an ecological basis, should focus on spacing. Trees must be widely spaced to prevent stand-destroying fire. Stands below 80 to $100 \mathrm{ft}^{2} /$ acre $\left(18.4\right.$ to $23 \mathrm{~m}^{2} / \mathrm{ha}$ ) of basal area are considered resistant to bark beetle attack (Schmid and Mata 1992), which suggests an upper stocking limit. Prescribed underburns every 10 to 20 years will maintain low fuel levels, destroy potential ladder fuels produced by Douglas-fir seedlings, and create seedbeds for ponderosa pine. Whenever the basal area exceeds $100 \mathrm{ft}^{2} /$ acre $\left(23 \mathrm{~m}^{2} / \mathrm{ha}\right)$, the stand should be thinned to 60 to $70 \mathrm{ft}^{2} /$ acre $\left(13.8\right.$ to $\left.16.1 \mathrm{~m}^{2} / \mathrm{ha}\right)$ leaving well-spaced, genetically desirable trees for seed and partial shade for pine seedlings. This management pattern emulates the narrow range of plant communities and natural processes experienced by these stands prior to Euro-American settlement and maintains a healthy sustainable forest in an ecologically sound manner.

\section{Douglas-fir}

Generally, Douglas-fir is not a preferred species for management where it has a climax role and ponderosa pine or lodgepole pine are potential seral dominants. Under these situations, Douglas-fir is susceptible to Douglas-fir beetle, western spruce budworm, dwarf mistletoe, and, in some areas, Douglas-fir tussock moth. Where Douglas-fir is the only management alternative, as in many of the eastside habitat types and phases, stand densities should be maintained below $120 \mathrm{ft}^{2} /$ acre $\left(27.5 \mathrm{~m}^{2} / \mathrm{ha}\right)$ to protect the stand from bark beetle attack (Furniss 1962, 1979). Douglasfir relies heavily on overstory shade for seedling establishment. The seedlings generally occur beneath tree canopies but in openings will also establish beneath canopies of certain shrubs. We do not know why tree seedlings occur beneath some shrub species more often than others. Of the common shrub species in central Idaho, snowbrush ceanothus (Ceanothus velutinus) provides the most favorable canopy for Douglas-fir seedlings; mountain snowberry (Symphoricarpos oreophilus) is the least favorable shrub. Unfortunately, in east-central Idaho where Douglas-fir regeneration is most desirable, most sites are too cool to support ceanothus.

\section{Natural Regeneration}

The conditions under which trees regenerate naturally are important not only from the standpoint of achieving new trees, but also from the standpoint of understanding the ecologic cycle of the site. The site conditions by which seral trees regenerate naturally provide a model for stand management and site treatment that are ecologically appropriate. Historical conditions leading to natural regeneration of the major tree species were covered briefly in the previous section. Prompt natural regeneration indicates that the site has begun a new successional cycle and humans have not disturbed the site beyond the point of easy recovery. Each species has a different evolutionary "strategy" even though the causal agent-fire-was the same.

Quaking Aspen and Lodgepole Pine-Natural regeneration of quaking aspen and lodgepole pine through stand-destroying wildfire provides a simple model of clearcutting and broadcast burning or, for lodgepole pine, a slightly more complex model of partial cutting to levels below 80 to $100 \mathrm{ft}^{2} /$ acre (18.4 to $23 \mathrm{~m}^{2} / \mathrm{ha}$ ) of basal area. Some bare soil is needed for lodgepole pine seed germination.

Ponderosa pine-Natural regeneration of ponderosa pine is more complex. It requires an open shelterwood system due to the large heavy seed, most of which disperse within 100 feet of the source. Table 5 shows the percentage of tree canopy and the stand basal area that produced the most ponderosa pine regeneration in samples of the respective habitat types. These data suggest that a 20 to 30 percent tree canopy and about $70 \mathrm{ft}^{2} /$ acre $\left(16.1 \mathrm{~m}^{2} / \mathrm{ha}\right)$ of basal area is the optimum stand structure in probably all situations but fire group five. With these site conditions, 
Table 5-Recommended strategy for natural regeneration of ponderosa pine.

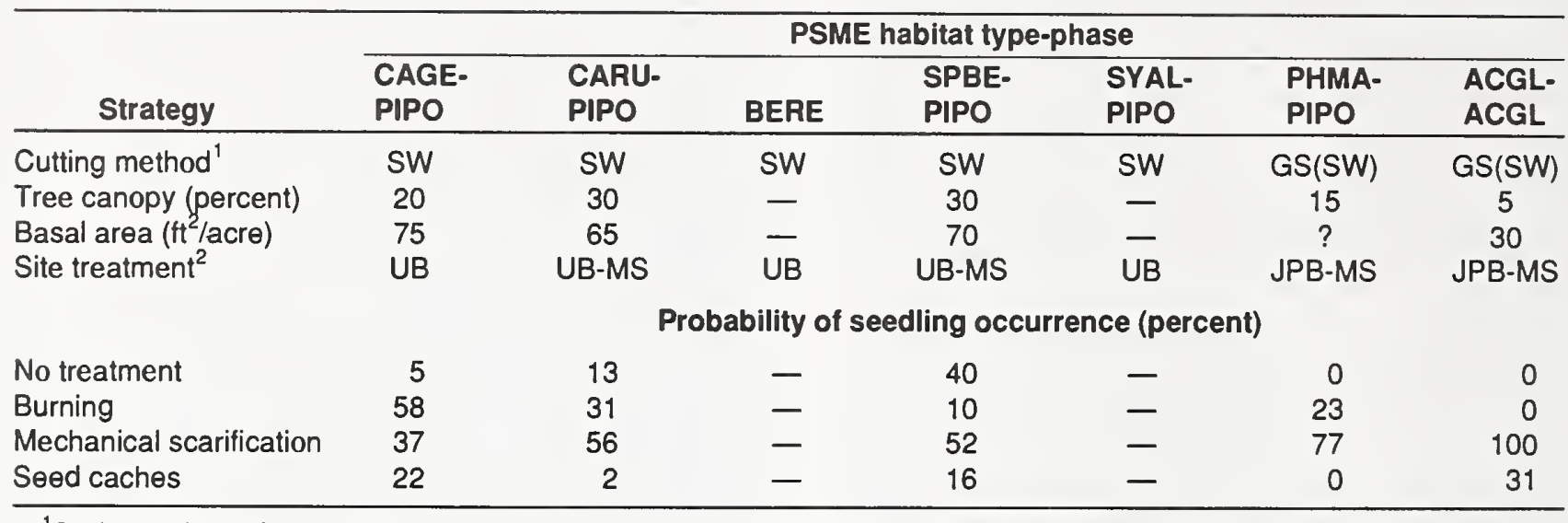

${ }^{1}$ Cutting methods: $S W=$ shelterwood; $G S=$ group selection $\left(<\frac{1}{2} A\right) ;()=$ occasional occurrence; $-=$ no data.

${ }^{2}$ Site treatments: UB = underburn; JPB = Jackpot burn; MS = mechanical scarification.

Douglas-fir generally dominates the stand and the undergrowth is a tall shrub layer. Some ponderosa pine may be established, but a group selection method is needed to provide enough fuel to treat the site with a high-intensity burn and provide enough sunlight for the pine seedlings. These small openings (about 0.25 acre [0.1 ha]) should be located within $100 \mathrm{ft}$ $(30.5 \mathrm{~m})$ of a ponderosa pine seed source or preferably planted with ponderosa pine.

On most sites, ponderosa pine regeneration depends largely on surface fires that coincide with intermittent cone crops. The fires must also burn hot enough to produce a seedbed and reduce competition. Where dense vegetation such as ninebark (Physocarpus malvaceus), elk sedge (Carex geyeri), or pinegrass (Calamagrostis rubescens) occurs, logging slash should be concentrated so burning will create enough heat to reduce the competition. In the natural system, surface fires that encountered fallen trees or large limbs created this effect.

Seed Caches-Ponderosa pine often regenerates from seed caches made by birds and rodents. Some habitat types seem to have more seed caches than others. For example, PSME/CAGE, PSME/SPBE, and
PSME/ACGL habitat types may have a substantial percentage of ponderosa pine regeneration in seed caches; PSME/CARU and PSME/PHMA may have very little (table 5). There are no data for the remaining two habitat types, PSME/BERE and PSME/SYAL, but these are expected to resemble the PSME/SPBE habitat types in seed cache percentages. The percentages shown in table 5 are minimal amounts because caches that produce only one tree cannot be recognized and recorded. The actual amount of ponderosa pine regeneration produced by seed caches may be much greater. One study (Vander Wall 1992) suggested that regeneration of pine from seed caches may be twice the observed amount.

Natural Regeneration Strategies-Table 5 outlines the recommended site treatment for the seven habitat types covered in this report. From an ecological perspective, some form of burning is the natural and recommended site treatment. Even though mechanical scarification from machine piling may produce a higher probability of survival for planted seedlings (table 6) due to less competition, seedling height growth may be greater on unscarified burned areas because the soil is less compacted and retains more

Table 6—Percent survival of planted ponderosa pine by site treatment and habitat type ${ }^{1}$.

\begin{tabular}{|c|c|c|c|c|c|c|c|}
\hline \multirow[b]{2}{*}{$\begin{array}{c}\text { Site } \\
\text { treatment }\end{array}$} & \multicolumn{7}{|c|}{ PSME habitat type-phase } \\
\hline & $\begin{array}{l}\text { CAGE- } \\
\text { PIPO }\end{array}$ & $\begin{array}{l}\text { CARU- } \\
\text { PIPO }\end{array}$ & BERE $^{2}$ & $\begin{array}{l}\text { SPBE- } \\
\text { PIPO }\end{array}$ & $\begin{array}{l}\text { SYAL- } \\
\text { PIPO }\end{array}$ & $\begin{array}{l}\text { PHMA- } \\
\text { PIPO }\end{array}$ & $\begin{array}{l}\text { ACGL- } \\
\text { ACGL }^{2}\end{array}$ \\
\hline Handscalps & 4 & 23 & 25 & 28 & - & 20 & 19 \\
\hline Broadcast burn & 32 & 29 & 47 & 33 & 65 & 40 & 43 \\
\hline Mechanical scarification & 23 & 26 & 40 & 36 & 82 & 28 & 22 \\
\hline Contour ditches/terraces & 58 & 44 & 56 & 74 & 81 & 76 & - \\
\hline
\end{tabular}

\footnotetext{
${ }^{1}$ All plantations are in clearcut areas.

${ }^{2}$ Upper elevations of habitat types are not suitable for ponderosa pine.
} 
humus (Minore 1986; Minore and Weatherly 1990). In the past many prescribed burns probably did not expose enough soil for suitable seedbeds; nor did they create enough hotspots to impede competition.

Although underburning is the natural treatment for most sites, jackpot burning (selective ignition of fuel concentrations) is recommended in the PSME/PHMA and PSME/ACGL habitat types. On many of these sites, Douglas-fir is currently the dominant species. This makes underburning impractical because underburning kills Douglas-fir more readily than ponderosa pine through needle and cambium scorch. If Douglasfir survives an underburn but is fire scarred, it becomes more susceptible to Douglas-fir beetle (Furniss 1965) and Schweinitzii root and butt rot (Barrett and Uscuplic 1971; Byler 1984). Jackpot burning should take place in small openings created by the group selection harvest method.

Where pinegrass is abundant and there is insufficient fuel to reduce the grass competition, some scarification may be needed. A bulldozer-mounted device, known locally as the Salmon Blade, has proven effective in pinegrass swards. This approach may be necessary in any of the habitat types supporting dense pinegrass. Any form of scarification with bulldozers should be done sparingly and at the correct time of year to minimize soil compaction. Compacted soils have been shown to limit tree seedling growth (Cochran and Brock 1985; Froelich 1979; Helms and Hipkin 1986) and in central Idaho can take 20 years or more to fully recover (Froelich and others 1985).

\section{Planted Regeneration}

Plantations are common in west-side phases of the seven habitat types but are much less common in the east-side phases. This is because ponderosa pine is the species most commonly planted. From the late 1950's to the 1970's many areas in west-central Idaho were clearcut, broadcast burned or machine scarified, and planted with ponderosa pine. Since stand-destroying wildfire is rarely part of the normal cycle in all but the PSME/PHMA and PSME/ACGL habitat types, clearcutting was ecologically inappropriate for most of these sites. It is not surprising that plantation survival was poor in large clearcuts since natural ponderosa pine regeneration normally depended on a partial tree canopy for protection from sun and wind. Table 6 shows percent survival of planted ponderosa pine during this era. More recent (late 1980's) plantations often have higher survival than shown in table 6 because the tree seedlings received better care in the nursery as well as during outplanting. Artificial shade was used more often and the clearings were not as large and exposed. Some recent plantations occur in large areas burned by wildfire, but standing dead trees and artificial shade devices help protect the tree seedlings.

For these reasons, plantation survival in recent years has often exceeded that shown in table 6 . However, a 20 to 30 percent tree canopy is still desirable and often essential for adequate survival of planted ponderosa pine in the PSME/CAGE, PSME/CARU, PSME/BERE, and PSME/SPBE habitat types.

Table 6 shows similar planting survival on broadcast burned and machine scarified areas for several habitat types, suggesting that either treatment is appropriate. However, our field observations reveal that when scarification is the result of machine piling slash into windrows, the growth and vigor of planted trees in the scarified areas are often poor compared to those growing in the burned windrows. A simple explanation is difficult because several factors are involved. The scarified areas may have compacted soils as demonstrated by Graham and others (1989), Minore (1986), and Minore and Weatherly (1990).

The scarified areas also may have lost nutrients and organic matter, which have been concentrated in the windrows (Morris and others 1983; Ross and others 1986). Or the burned windrows may have higher nutrient levels due to the burning. Regardless of the reason, we do not recommend dozer piling of slash as a site treatment in Douglas-fir habitat types.

Plantation survival data for lodgepole pine and Douglas-fir are too sparse for meaningful results. Limited data for lodgepole pine suggest that lodgepole pine can be planted in clearings with good success wherever it is a major seral species. When it is planted offsite, either inadvertently or to provide site protection for Douglas-fir, survival is generally low and tree development is poor. In these dry habitat types, Douglas-fir seedlings, whether planted or natural, need protection from sun and wind. For this reason, plantation success of Douglas-fir is generally low and planting in unshaded clearings is not recommended.

\section{Tree Growth}

Growth capability of trees in the seedling to young sapling stage is an important consideration wherever competition from shrubs and graminoids occurs. Tall-growing shrubs are stimulated by increased sunlight and can suppress planted conifers to the point of causing plantation failure in spite of high first-year survival. Intense root competition from shrubs and graminoids also affects the growth of young trees and varies with habitat type, existing vegetation, and site treatment.

The simplest expression of early tree growth is the number of years required to reach a height of $4.5 \mathrm{ft}$ $(1.4 \mathrm{~m})$. Table 7 shows these values for ponderosa pine under four site treatments. It should be noted that 
Table 7-Years required for planted ponderosa pine to reach $4 \frac{1}{2}$ feet in height.

\begin{tabular}{lcccc}
\hline $\begin{array}{c}\text { PSME habitat } \\
\text { type-phase }\end{array}$ & $\begin{array}{c}\text { Hand } \\
\text { scalps }\end{array}$ & $\begin{array}{c}\text { Broadcast } \\
\text { burn }\end{array}$ & $\begin{array}{c}\text { Machine } \\
\text { scarified }\end{array}$ & $\begin{array}{c}\text { Contour } \\
\text { terrace/ditch }\end{array}$ \\
\hline CAGE-PIPO & 14.0 & 10.0 & 10.0 & 9.0 \\
CARU-PIPO & 11.0 & 9.0 & 12.0 & 8.0 \\
BERE & 10.0 & 9.0 & 9.0 & 10.0 \\
SPBE-PIPO & 12.0 & 8.0 & 9.0 & 8.0 \\
SYAL-PIPO & 9.5 & 7.5 & 8.0 & 6.5 \\
PHMA-PIPO & 10.0 & 8.0 & 9.0 & 8.0 \\
ACGL-ACGL & 10.0 & 11.0 & 10.0 & - \\
\hline
\end{tabular}

hand scalping, which minimally reduces competition, often results in slower growing seedlings when compared with other treatments. This difference emphasizes the importance of large, effective scalps when no other treatment is applied. For example, where elk sedge is the predominant cover, 4- by 4 - $\mathrm{ft}$ (1.2- by $1.2-\mathrm{m}$ ) scalps are needed to effectively reduce competition (Sloan and Ryker 1986). A 5-ft (1.5-m) scalp is recommended where ceanothus species are the predominant competition (McDonald and Fiddler 1989). Clearly scalps of this size are not practical on terrain too steep for machinery. Chemical controls are a logical alternative to manual scalping. Some of the newer chemicals such as glyphosate (Roundup) and hexazinone (Velpar) are effective on young ( $<3$ years old) shrubs, graminoids, and herbs (Boyd and others 1985; McDonald and Fiddler 1989) and have little if any environmental impact. For instance, glyphosate decomposes in soil and when applied at its most concentrated recommended mixture has no effect on soil microbial biomass (Wardle and Parkinson 1991). Both glyphosate and hexazinone are less toxic to animals than caffeine. Hexazinone, the more toxic of the two, has roughly the same toxicity as aspirin (McNabb 1991). Other relatively new herbicides such as imazapyr (Arsenal), sulfometuron methyl (Oust), and picloram (Tordon) are less toxic than common table salt (McNabb 1991).
Growth capability of larger trees can be expressed as site index. Table 8 shows site indexes of major tree species in the seven habitat types. The low values shown for lodgepole pine in west-central Idaho reflect the fact that lodgepole pine is at its warm, dry limits in these habitat types. Even though lodgepole pine is easily regenerated, it may be short-sighted management to encourage lodgepole pine at the expense of ponderosa pine or Douglas-fir. Growth rates of all tree species present should be considered before timber harvest and regeneration plans are made.

\section{Shrub Layer}

Shrub layer succession is easily predicted on these dry habitat types because relatively few species are present on any one site. Tables 9 and 10 list the major shrub species and their successional roles in the seven habitat types. Although most shrub species have the same successional role in all seven habitat types, some species have different roles, such as late seral in one habitat type versus climax in another. These differences become more pronounced over a broader range of habitat types. For example, a species' successional role may vary widely among the ponderosa pine, Douglas-fir, and grand fir (Abies grandis) series. It is likely that a given shrub species may be climax in

Table 8-Site indexes in feet (50-year base) for major Douglas-fir habitat types in central Idaho.

\begin{tabular}{lcccccc}
\hline $\begin{array}{c}\text { PSME habitat } \\
\text { type-phase }\end{array}$ & $\begin{array}{c}\text { Pinus } \\
\text { contorta }\end{array}$ & $\begin{array}{c}\text { Pinus } \\
\text { ponderosa }\end{array}$ & $\begin{array}{c}\text { Pseudotsuga } \\
\text { menziesii }\end{array}$ & $\begin{array}{c}\text { PSME habitat } \\
\text { type-phase }\end{array}$ & $\begin{array}{c}\text { Pinus } \\
\text { contorta }\end{array}$ & $\begin{array}{c}\text { Pseudostuga } \\
\text { menziesii }\end{array}$ \\
\hline & $\ldots \ldots \ldots$ & - West-central ldaho & $\ldots \ldots \ldots$ & $\ldots$ & & $\ldots$ \\
CAGE-PIPO & $32 \pm 6$ & $53 \pm 7$ & $53 \pm 4$ & CAGE-CAGE & $48 \pm ?$ & $54 \pm 4$ \\
CARU-PIPO & $30 \pm 8$ & $61 \pm 5$ & $56 \pm 7$ & CARU-CARU & $50 \pm 10$ & $52 \pm 5$ \\
BERE & - & $58 \pm 12$ & $61 \pm 7$ & SPBE -CARU & - & $46 \pm$ ? \\
SPBE-PIPO & - & $58 \pm 4$ & $57 \pm 4$ & SYAL-SYAL & - & $50 \pm 9$ \\
SYAL-PIPO & - & $66 \pm 5$ & $60 \pm 6$ & PHMA-PSME & - & $52 \pm 10$ \\
PHMA-PIPO & - & $62 \pm 4$ & $60 \pm 6$ & ACGL-SYOR & - & $42 \pm 20$ \\
ACGL-ACGL & - & $67 \pm ?$ & $71 \pm 20$ & & & \\
\hline
\end{tabular}


Table 9-Successional role of important shrub species in major Douglas-fir habitat types of west-central Idaho.

\begin{tabular}{|c|c|c|c|c|c|c|c|}
\hline \multirow[b]{2}{*}{$\begin{array}{c}\text { Shrub } \\
\text { species }\end{array}$} & \multicolumn{7}{|c|}{ PSME habitat type-phase } \\
\hline & $\begin{array}{l}\text { CAGE- } \\
\text { PIPO }\end{array}$ & $\begin{array}{l}\text { CARU- } \\
\text { PIPO }\end{array}$ & BERE & $\begin{array}{l}\text { SPBE- } \\
\text { PIPO }\end{array}$ & $\begin{array}{l}\text { SYAL- } \\
\text { PIPO }\end{array}$ & $\begin{array}{l}\text { PHMA- } \\
\text { PIPO }\end{array}$ & $\begin{array}{l}\text { ACGL- } \\
\text { ACGL }\end{array}$ \\
\hline Acer glabrum & - & $a^{1}$ & a & a & a & (C) & C \\
\hline Amelanchier alnifolia & LS & LS & LS & LS & LS & LS & LS \\
\hline Artemisia tridentata & ES & (es) & (es) & a & a & - & - \\
\hline Berberis repens & (c) & c & $\mathrm{C}$ & c & c & c & (C) \\
\hline Ceanothus velutinus & (ES) & ES & ES & ES & ES & ES & ES \\
\hline Ceanothus sanguineus & - & - & - & (ES) & - & (ES) & - \\
\hline Cercocarpus ledifolius & - & - & - & - & - & - & - \\
\hline Chrysothamnus nauseosus & es & a & es & es & $a$ & a & - \\
\hline Chrysothamnus viscidiflorus & es & 一 & a & - & - & - & - \\
\hline Juniperus communis & - & - & - & - & - & - & - \\
\hline Lonicera utahensis & - & a & a & - & a & (Is) & Is \\
\hline Philadelphus lewisii & - & - & - & (ms) & - & (MS) & - \\
\hline Physocarpus malvaceus & - & - & - & (c) & (c) & C & (c) \\
\hline Prunus emarginata & (MS) & (MS) & (MS) & (MS) & (MS) & MS & MS \\
\hline Prunus virginiana & MS & MS & MS & MS & MS & MS & MS \\
\hline Purshia tridentata & ES & ES & (es) & ES & (ES) & (es) & - \\
\hline Ribes cereum & ES & ES & ES & $\overline{\mathrm{ES}}$ & ES & ES & es \\
\hline Ribes viscosissimum & (es) & es & es & es & es & (ES) & ES \\
\hline Rubus parviflorus & - & - & - & - & - & (LS) & (LS) \\
\hline Salix scouleriana & (ms) & (MS) & (ms) & MS & MS & MS & (MS) \\
\hline Sambucus caerulea & es & es & es & es & es & es & es \\
\hline Shepherdia canadensis & - & $a$ & - & (es) & - & - & $a$ \\
\hline Spiraea betulifolia & c & c & - & $\mathrm{C}$ & (C) & LS & LS \\
\hline Symphoricarpos albus & - & (c) & - & (c) & C & (LS) & $a$ \\
\hline Symphoricarpos oreophilus & LS & LS & LS & LS & Is & LS & LS \\
\hline Sorbus scopulina & - & a & c & (c) & c & c & c \\
\hline Vaccinium globulare & - & - & - & - & a & (C) & (C) \\
\hline
\end{tabular}

${ }^{1} E S$ = early seral; $a=$ accidental; MS = mid seral; ( ) = occurs in only part of the habitat type; LS = late seral; upper case = major species occurrence; $\mathrm{C}=$ climax; lower case $=$ minor species occurrence.

Table 10-Successional role of important shrub species in major Douglas-fir habitat types of east-central Idaho.

\begin{tabular}{|c|c|c|c|c|c|c|}
\hline \multirow[b]{2}{*}{$\begin{array}{l}\text { Shrub } \\
\text { species }\end{array}$} & \multicolumn{6}{|c|}{ PSME habitat type-phase } \\
\hline & $\begin{array}{l}\text { CAGE- } \\
\text { CAGE }\end{array}$ & $\begin{array}{l}\text { CARU- } \\
\text { CARU }\end{array}$ & $\begin{array}{l}\text { SPBE- } \\
\text { CARU }\end{array}$ & $\begin{array}{l}\text { SYAL- } \\
\text { SYAL }\end{array}$ & $\begin{array}{l}\text { PHMA- } \\
\text { PSME }\end{array}$ & $\begin{array}{l}\text { ACGL- } \\
\text { SYOR }\end{array}$ \\
\hline Acer glabrum & - & $a^{9}$ & (c) & (c) & (c) & C \\
\hline Amelanchier alnifolia & Is & (Is) & (Is) & (LS) & (LS) & (Is) \\
\hline Artemisia tridentata & ES & ES & ES & a & (es) & (es) \\
\hline Berberis repens & (c) & c & c & c & (c) & - \\
\hline Ceanothus velutinus & (ES) & (ES) & (ES) & - & (ES) & (es) \\
\hline Ceanothus sanguineus & - & - & - & - & - & - \\
\hline Cercocarpus ledifolius & - & - & - & - & (MS) & (MS) \\
\hline Chrysothamnus nauseosus & es & ES & ES & es & a & - \\
\hline Chrysothamnus viscidiflorus & es & es & es & - & - & a \\
\hline Juniperus communis & a & - & - & a & (Is) & (LS) \\
\hline Lonicera utahensis & 二 & - & - & a & a & - \\
\hline Philadelphus lewisii & - & - & 一 & - & (ms) & - \\
\hline Physocarpus malvaceus & - & - & a & (c) & $\mathrm{C}$ & (c) \\
\hline Prunus emarginata & $a$ & a & - & (1) & a & - \\
\hline Prunus virginiana & (ms) & (ms) & (ms) & MS & (MS) & (LS) \\
\hline Purshia tridentata & (es) & (ES) & (ES) & (es) & $a$ & - \\
\hline Ribes cereum & MS & MS & MS & ES & ES & ES \\
\hline Ribes viscosissimum & (ms) & (MS) & (MS) & (es) & (es) & (es) \\
\hline Rubus parviflorus & - & - & - & - & - & - \\
\hline Salix scouleriana & (ms) & (ms) & (MS) & a & (ms) & a \\
\hline Sambucus spp. & (es) & (es) & a & a & - & - \\
\hline Shepherdia canadensis & 100 & (es) & (ES) & (ES) & a & (ES) \\
\hline Spiraea betulifolia & - & c & C & (C) & (LS) & - \\
\hline Symphoricarpos albus & 一 & - & $c$ & C & (Is) & - \\
\hline Symphoricarpos oreophilus & LS & LS & LS & LS & LS & $\mathrm{C}$ \\
\hline Sorbus scopulina & - & - & a & a & - & - \\
\hline Vaccinium globulare & - & 一 & - & - & - & - \\
\hline
\end{tabular}

${ }^{1} E S=$ early seral; $a=$ accidental; $M S$ = mid seral; ()$=$ occurs in only part of the habitat type; $L S=$ late seral; upper case = major species occurrence; $\mathrm{C}=$ climax; lower case $=$ minor species occurrence. 
the pine series and early seral in the grand fir series. The trend is for species to occupy seral roles in more moderate environments.

Fortunately successional strategies of plant species do not change across habitat types. If a species is highly shade tolerant or stores its seed in the soil in one area, it will have these same characteristics wherever it occurs. Even closely related species within a genus have similar successional strategies.
Table 11 lists the major shrub species, their successional strategies, and responses to disturbance. It is important to consider reproduction methods of major shrub species to avoid excessive competition with tree seedlings. For example, if an early seral species that stores seed in the soil such as Ceanothus or Ribes is present in small amounts in older successional stages, it is likely that much seed is present in the soil or litter. If a favorable disturbance occurs

Table 11-Successional strategies and disturbance responses of major shrub species.

\begin{tabular}{|c|c|c|c|c|c|c|}
\hline \multirow[b]{2}{*}{$\begin{array}{l}\text { Shrub } \\
\text { species }\end{array}$} & \multirow[b]{2}{*}{$\begin{array}{l}\text { Seed transport; } \\
\text { reproduction methods }\end{array}$} & \multicolumn{5}{|c|}{ Type of disturbance $^{1}$} \\
\hline & & $\begin{array}{l}\text { CC, } \\
\text { NP }\end{array}$ & $\begin{array}{l}\text { SC, } \\
\text { MS }\end{array}$ & $\begin{array}{l}\text { CC, } \\
\text { MS }\end{array}$ & $\begin{array}{l}\text { CC, } \\
\text { BB }\end{array}$ & WF \\
\hline Acer glabrum & $\begin{array}{l}\text { Wind; not stored in soil. Germinates in partial shade on soil. } \\
\text { Stumps resprout. }\end{array}$ & $V^{2}$ & V-s & V & V & V \\
\hline Amelanchier alnifolia & $\begin{array}{l}\text { Birds, mammals; not stored in soil. Germinates on bare } \\
\text { soil in partial shade. Stumps resprout. }\end{array}$ & v & v-s & $v-s$ & $v-s$ & v-s \\
\hline Artemisia tridentata & $\begin{array}{l}\text { Wind; not stored in soil. Germinates on bare soil in full sun. } \\
\text { Nonrhizomatous. }\end{array}$ & $\mathrm{n}$ & $\mathrm{D}$ & D-S & D-S & D.S \\
\hline Ceanothus spp. & $\begin{array}{l}\text { No obvious transport; stored in soil ( } 91 \text { percent viable) }{ }^{3} \text { : } \\
\text { germinates, mainly after burning, in full sun. }\end{array}$ & $n$ & $d$ & $d-s$ & $\mathrm{~S}$ & $\mathrm{~S}$ \\
\hline Cercocarpus ledifolius & Wind, mammals; may store in soil. Germinates in full sun. & v & v & $v-s$ & s & s \\
\hline Chrysothamnus spp. & $\begin{array}{l}\text { Wind; not stored in soil. Germinates on bare soil in full sun. } \\
\text { Nonrhizomatous. }\end{array}$ & $\mathrm{n}$ & D & D-S & D-S & D-S \\
\hline Juniperus communis & Birds; not stored in soil. Germinates in full sun or partial shade. & $\mathrm{n}$ & D-s & D-s & D-s & D-s \\
\hline Philadelphus lewisii & $\begin{array}{l}\text { No obvious transport; storage capability unknown. } \\
\text { Germinates in full sun. Stumps resprout. }\end{array}$ & v & v & $v-s$ & $v-s$ & $v-s$ \\
\hline Physocarpus malvaceus & $\begin{array}{l}\text { No obvious transport; seed stored in soil ( } 11 \text { percent viable) }{ }^{3} \text {. } \\
\text { Germinates in partial shade on bare soil. Increases by } \\
\text { root sprouts. }\end{array}$ & V & V-s & V & V & V \\
\hline Prunus spp. & $\begin{array}{l}\text { Birds, mammals; stored in soil ( } 27 \text { percent viable). Germinates } \\
\text { in full sun following scarification or burning. Increases by } \\
\text { root sprouts. }\end{array}$ & V & v & V-s & V-s & V-s \\
\hline Purshia tridentata & $\begin{array}{l}\text { Small rodents; not stored in soil. Germinates best on } \\
\text { scarified soil in full sun. Nonrhizomatous. }\end{array}$ & n & $\mathrm{D}$ & D-S & D-s & D-s \\
\hline Ribes spp. & $\begin{array}{l}\text { Birds, mammals; stored in soil ( } 96 \text { percent viable). } \\
\text { Germinates on bare soil in full sun. }\end{array}$ & $\mathbf{n}$ & d & $d-S$ & S & s \\
\hline Rubus parviflorus & $\begin{array}{l}\text { Birds, mammals; stored in soil ( } 14 \text { percent viable). Increases } \\
\text { by rhizomes. }\end{array}$ & V & $d$ & $d$ & V-s & V-s \\
\hline Salix scouleriana & $\begin{array}{l}\text { Wind; not stored in soil. Germinates on moist mineral soil } \\
\text { in full sun. Stumps resprout. }\end{array}$ & V & v & V-s & V-s & V-s \\
\hline Shepherdia canadensis & $\begin{array}{l}\text { Birds, mammals; possibly stored in soil. Germinates on bare } \\
\text { soil in full sun. }\end{array}$ & n & d & $d-s$ & S & $\mathrm{S}$ \\
\hline Spiraea betulifolia & No obvious transport; not stored in soil. Increases by rhizomes. & V & v & V & V & V \\
\hline Symphoricarpos albus & Birds, mammals; not stored in soil. Increases by rhizomes. & V & v & V & V & V \\
\hline Symphoricarpos oreophilus & $\begin{array}{l}\text { Birds, mammals; not stored in soil. Germinates on bare soil } \\
\text { in partial shade. Stumps resprout. }\end{array}$ & v & d-s & $d-s$ & v-s & $v-s$ \\
\hline Sorbus scopulina & $\begin{array}{l}\text { Birds, mammals; not stored in soil. Germinates on bare soil } \\
\text { in partial shade. Stumps resprout. }\end{array}$ & V & $V-s$ & V & V & V \\
\hline Vaccinium globulare & $\begin{array}{l}\text { Birds, mammals; stored in soil ( } 23 \text { percent viable). Germinates } \\
\text { in partial shade on moist soil. Increases by shallow rhizomes. }\end{array}$ & v & D-s & $\mathrm{D}$ & v & v \\
\hline
\end{tabular}

${ }^{1}$ Disturbance codes: CC, NP = clearcut, no site preparation; CC, MS = clearcut, mechanical scarification; SC, MS = shelterwood cut, mechanical scarification; $\mathrm{CC}_{\mathrm{B}} \mathrm{BB}=$ clearcut, broadcast burned; $\mathrm{WF}=$ stand-destroying wildfire.

${ }^{1}$ Response codes: $V=$ vegetative increase from existing plants following tree removal (may be offset by treatment intensity); $S=$ seedling response (coverage increase depends on amount of viable seed available and may be influenced by treatment type and intensity); $D=$ decrease in existing canopy coverage; $n=$ no appreciable change; upper case letters = major change in species coverage; lower case letters = minor change in species coverage.

${ }^{3}$ Stored seed viabilities are from Kramer (1984). 
(table 11), the seed could germinate profusely and create severe competition for tree seedlings. Or, if species with wind transported seed such as Chrysothamnus or Salix are abundant nearby and a suitable seedbed is created, these strong competitors could quickly dominate the site. There are instances when certain shrub species may be desirable for wildlife. In these cases the information in table 11 can be used to encourage certain shrub species rather than avoid them. It is easier to manage shrub occurrence by manipulating regeneration opportunities rather than through direct control. Most shrub species that occur on Douglas-fir habitat types have deep, extensive root systems. When top-killed, most of these species resprout from a variety of depths below ground (Bradley 1984). If the tree canopy is also killed, as in a wildfire, the resprouting shrubs as well as those germinating from buried seed, can easily achieve greater canopy coverages than existed before the fire.

Of the resprouting shrub species, Scouler willow (Salix scouleriana) probably creates the most problems for silviculturists. Beneath a mid-seral tree canopy, this tall-growing shrub usually exhibits a narrow upright form. It occupies relatively little growing space and to the inexperienced observer appears rather innocuous. But if the tree canopy is removed and the willow top-killed, as from wildfire or logging (fig. 6a), the willow resprouts vigorously creating a round form that may reach $16 \mathrm{ft}(4.9 \mathrm{~m})$ in diameter (fig. 6b). Where stands contain depauperate willows at high densities, such as one every $16 \mathrm{ft}(4.9 \mathrm{~m})$,

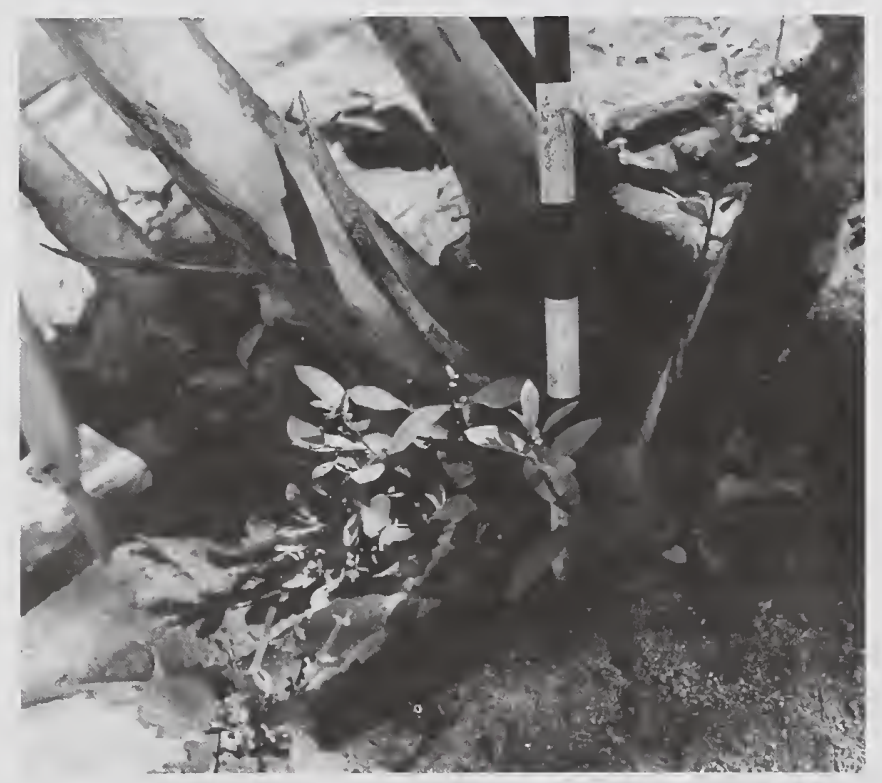

Figure 6a-Scouler willow resprouts 3 weeks after topkilling by an August wildfire. The $0.7 \mathrm{ft}$ $(0.2 \mathrm{~m})$ tall resprouts are already being browsed by big game.

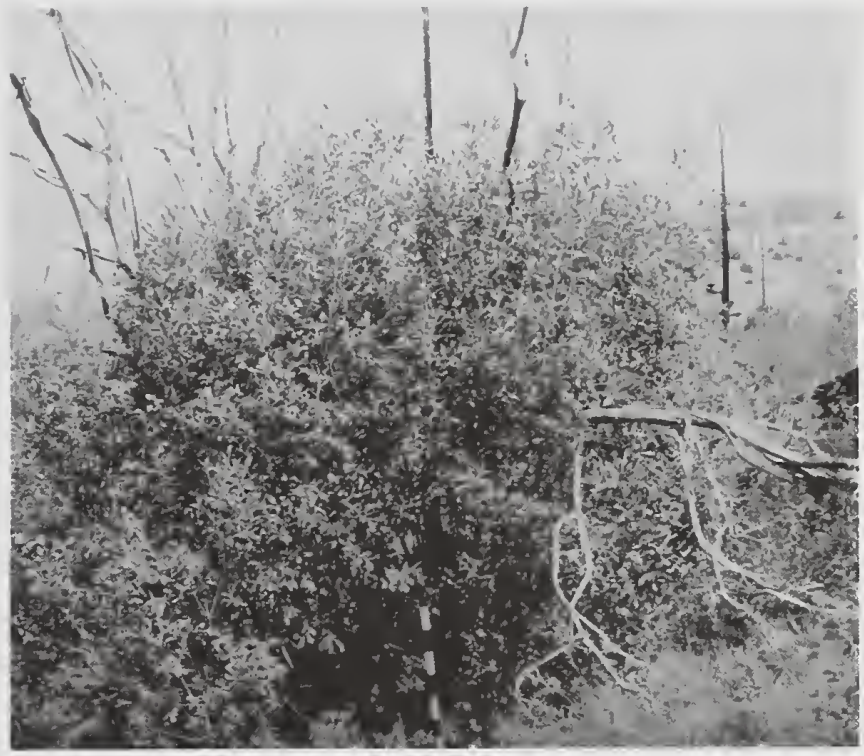

Figure $6 b-$ The same Scouler willow five growing seasons later. The resprouted willow is now $12 \mathrm{ft}(3.7 \mathrm{~m})$ tall and almost $16 \mathrm{ft}(5 \mathrm{~m})$ wide.

there is little opportunity to grow shade intolerant ponderosa pine if the tree canopy is removed. Since Scouler willows produce deep extensive root systems, it is impractical to mechanically remove them. Unless an herbicide can be used to kill the willow, shade tolerant Douglas-fir must be selected for management. To a certain extent, the willow/Douglas-fir relationship is self-perpetuating. Once Douglas-fir occupies the site, it poses greater risk of a stand-destroying fire than ponderosa pine. This type of fire creates the most favorable seedbed and growing conditions for the willow, which in turn promotes another stand of Douglas-fir.

Of the shrub species germinating from buried seed, snowbrush ceanothus (Ceanothus velutinus) is the most prolific (fig. 7). Viable seed occurs in most westside phases of Douglas-fir habitat types. Two notable exceptions are frost-prone areas where it is too cold for the ceanothus and in drainages just east of Hells Canyon where, for unknown reasons, the ceanothus distribution is quite spotty. In this latter area, Kramer (1984) recorded four mature stands in PSME/PHMA habitat type that lacked buried ceanothus seed. This was the only area sampled in PSME/PHMA that lacked buried ceanothus seed. As a general rule, if ceanothus is present in disturbed areas nearby, such as along roads or skid trails, it is a virtual certainty that the seed lies buried in more shaded areas. The seed is viable for 200 to 300 years (Gratkowski 1962) and possibly over 500 years (Zavitkovski and Newton 1968). Heat, such as from burning, initiates germination (Gratkowski 1962). High intensity broadcast 


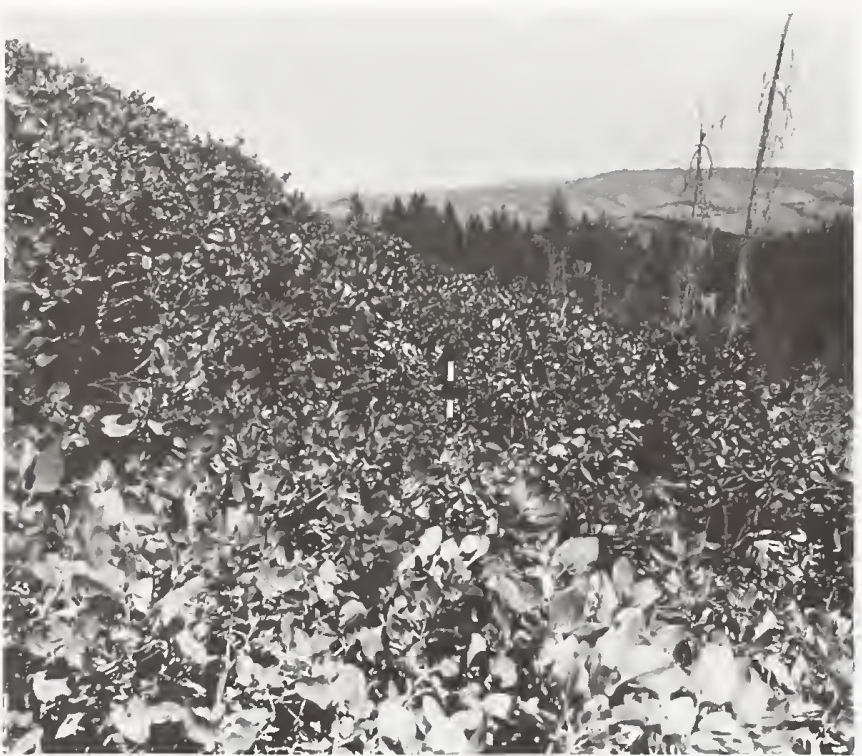

Figure 7-Eleven years after broadcast burning this site is fully occupied by Ceanothus germinating from buried seed.

burns or stand-destroying wildfire can result in 100 percent cover of ceanothus in about 10 years. The shrub canopy discourages ponderosa pine establishment and favors Douglas-fir, which predisposes the site to another high-intensity fire. A dense ceanothus canopy can restrict livestock and protect the site from erosion. Ceanothus also fixes nitrogen (Binkley and others 1982; Youngberg and Wollum 1976) and provides big game browse and songbird habitat (Thomas 1979).

The successional strategies of ceanothus, Scouler willow, and possibly other species can be disrupted by weather, insects, or disease. We have observed high coverages of snowbrush ceanothus decimated by the combination of abnormally low snow cover, cold temperatures, and by outbreaks of the western tussock moth (Orgyia cana). We have also seen high coverages of Scouler willow decimated by an unidentified rust. In most cases, the affected shrubs resprout but lose their competitive advantage to the extent that the plant community advances to a later seral stage within one growing season. These kinds of events make it difficult to predict the duration of seral stages but generally do not change the course of succession.

\section{Herb Layer}

Herb layer succession is usually more complex than the tree and shrub layers because more species are involved. Tables 12 and 13 list the major herb layer species and their successional roles. The same relationships of successional roles and strategies discussed for the shrub layer also apply to herb layer species. Table 14 lists successional strategies of the major herb layer species.

Of the herb layer species listed, only a few cause major management problems. Among the graminoids, pinegrass, elk sedge, and the introduced species, smooth brome (Bromus inermis), can create severe competition for tree seedlings, mainly through extensive root and rhizome development. On dry forest sites, graminoids effectively restrict tree and shrub regeneration from seed by depleting soil moisture prior to seedling development (Schultz and others 1955). Planted tree seedlings also have poor survival and growth among established grasses (fig. 8) (Larson and Schubert 1969; McDonald 1986; Petersen 1988). The 2- by 2 -ft $(0.6$ - by $0.6-\mathrm{m})$ scalp commonly used for tree planting is inadequate for eliminating competition of graminoids due to their extensive root systems (McDonald and Fiddler 1989; Sloan and Ryker 1986).

On the positive side, these graminoids are effective soil binders and resprout quickly after burning, thereby reducing the potential for soil erosion. A single elk sedge plant, though only $1-\mathrm{ft}(0.3-\mathrm{m})$ tall, can have a fibrous root system 4.5 -ft $(1.4-\mathrm{m})$ wide and 6-ft (1.8-m) deep (Sloan and Ryker 1986). Smooth brome is so effective at stabilizing soils and excluding trees and tall-growing shrubs that it makes an ideal roadside cover since it maintains good visibility and prevents erosion. It is also highly palatable to livestock (Hassell and others 1983). Pinegrass and elk sedge also provide good forage for big game and livestock. Pinegrass was shown to have higher protein content than timothy or orchardgrass from late June to mid-September (McLean and Clark 1980). Elk sedge has high forage value for elk (Kufeld 1973), cattle (USDA 1986), and in early spring, black bear (Beecham 1981).

Most perennial forbs present few problems for land managers even though some species can have spectacular responses to certain disturbances. For example, mountain hollyhock (Iliamna rivularis) can germinate profusely from buried seed after a high-severity fire. Fireweed (Epilobium angustifolium) can increase dramatically from rhizomes and windborne seed after a fire. If machine scarification is used, sticky cinquefoil (Potentilla glandulosa) can germinate from buried seed and quickly dominate the site. All of these species add considerable color to the landscape when flowering in high densities.

A few other forb responses are less showy and less benign. Western coneflower (Rudbeckia occidentalis) can increase substantially with grazing, particularly on finer textured soils. Natural tree regeneration beneath the coneflower is quite limited, possibly due 
Table 12-Successional role of important herb layer species in major Douglas-fir habitat types of west-central Idaho.

\begin{tabular}{|c|c|c|c|c|c|c|c|}
\hline \multirow[b]{2}{*}{$\begin{array}{l}\text { Herb layer } \\
\text { species }\end{array}$} & \multicolumn{7}{|c|}{ PSME habitat type-phase } \\
\hline & $\begin{array}{l}\text { CAGE- } \\
\text { PIPO }\end{array}$ & $\begin{array}{l}\text { CARU- } \\
\text { PIPO }\end{array}$ & BERE & $\begin{array}{l}\text { SPBE- } \\
\text { PIPO }\end{array}$ & $\begin{array}{l}\text { SYAL- } \\
\text { PIPO }\end{array}$ & $\begin{array}{l}\text { PHMA- } \\
\text { PIPO }\end{array}$ & $\begin{array}{l}\text { ACGL- } \\
\text { ACGL }\end{array}$ \\
\hline \multicolumn{8}{|l|}{ Perennial graminoids } \\
\hline $\begin{array}{l}\text { Agropyron intermedium } \\
\text { Agropyron spicatum } \\
\text { Bromus carinatus } \\
\text { Bromus inermis } \\
\text { Calamagrostis rubescens } \\
\text { Carex geyeri } \\
\text { Carex rossii } \\
\text { Festuca idahoensis } \\
\text { Festuca occidentalis } \\
\text { Poa nervosa } \\
\text { Stipa occidentalis }\end{array}$ & $\begin{array}{l}(E S)^{1} \\
\text { ES } \\
\text { ES } \\
\text { a } \\
\text { (c) } \\
\text { C } \\
\text { es } \\
\text { ls } \\
\text { c } \\
\text { (ES) }\end{array}$ & $\begin{array}{l}\text { (es) } \\
\text { (es) } \\
\text { ES } \\
\text { a } \\
\text { C } \\
\text { LS } \\
\text { ES } \\
\text { Is } \\
\text { ms } \\
\text { LS } \\
\text { es }\end{array}$ & $\begin{array}{l}\text { (es) } \\
\text { (es) } \\
\text { ES } \\
\mathrm{ms} \\
\mathrm{C} \\
\mathrm{LS} \\
\mathrm{ES} \\
- \\
\mathrm{ms} \\
\mathrm{LS} \\
\text { (ES) }\end{array}$ & $\begin{array}{l}(\mathrm{ES}) \\
\text { (ES) } \\
\text { ES } \\
\mathrm{ms} \\
\mathrm{C} \\
\text { LS } \\
\text { ES } \\
\text { a } \\
\mathrm{ms} \\
\text { LS } \\
\text { es }\end{array}$ & $\begin{array}{l}\text { (ES) } \\
\text { (es) } \\
\text { ES } \\
\text { MS } \\
\text { C } \\
\text { LS } \\
\text { es } \\
\text { Is } \\
\text { ms } \\
\text { Is } \\
\text { (es) }\end{array}$ & $\begin{array}{l}\text { (ES) } \\
\text { (es) } \\
\text { (ES) } \\
\text { MS } \\
\text { (C) } \\
\text { LS } \\
\text { es } \\
\text { a } \\
\text { ms } \\
\text { LS } \\
\text { a }\end{array}$ & $\begin{array}{l}\text { (ES) } \\
\text { (es) } \\
\text { ES } \\
\text { MS } \\
\text { C } \\
\text { LS } \\
\text { es } \\
\frac{\text { MS }}{\text { Is }} \\
\text { a }\end{array}$ \\
\hline \multicolumn{8}{|l|}{ Perennial herbs } \\
\hline $\begin{array}{l}\text { Agastache urticifolia } \\
\text { Antennaria microphylla } \\
\text { Antennaria racemosa } \\
\text { Apocynum androsaemifolium } \\
\text { Arenaria macrophylla } \\
\text { Arnica cordifolia } \\
\text { Aster conspicuus } \\
\text { Aster perelegans } \\
\text { Astragalus miser }\end{array}$ & $\begin{array}{l}\text { (ES) } \\
\mathrm{ms} \\
- \\
\mathrm{LS} \\
\mathrm{c} \\
\mathrm{C} \\
\text { (C) } \\
\mathrm{MS} \\
-\end{array}$ & $\begin{array}{l}\text { a } \\
\mathrm{ms} \\
\mathrm{c} \\
\mathrm{MS} \\
\mathrm{c} \\
\mathrm{C} \\
\mathrm{LS} \\
\mathrm{ms} \\
-\end{array}$ & $\begin{array}{l}\mathrm{a} \\
\mathrm{ms} \\
- \\
\mathrm{MS} \\
\mathrm{c} \\
\mathrm{C} \\
\mathrm{LS} \\
\mathrm{ms} \\
-\end{array}$ & $\begin{array}{l}\text { es } \\
\text { es } \\
\text { (c) } \\
\text { MS } \\
\text { c } \\
\text { C } \\
\text { LS } \\
\text { MS } \\
-\end{array}$ & $\begin{array}{l}\text { es } \\
\text { es } \\
\text { (c) } \\
\text { MS } \\
\text { c } \\
\text { C } \\
\text { LS } \\
\text { ms } \\
-\end{array}$ & $\begin{array}{l}\text { (ES) } \\
\text { a } \\
\text { (LS) } \\
\text { MS } \\
\text { LS } \\
\text { C } \\
\text { LS } \\
\text { ms } \\
-\end{array}$ & $\begin{array}{l}\text { ES } \\
\text { a } \\
\text { (c) } \\
\text { MS } \\
\text { c } \\
\text { C } \\
\text { LS } \\
\text { ms } \\
\text { - }\end{array}$ \\
\hline Balsamorhiza sagittata & MS & $\mathrm{ms}$ & $\mathrm{ms}$ & MS & (MS) & (MS) & MS \\
\hline Castilleja miniata & $\mathrm{ms}$ & $\mathrm{ms}$ & $\mathrm{ms}$ & MS & MS & MS & MS \\
\hline Epilobium angustifolium & $\mathrm{ms}$ & (MS) & $(\mathrm{ms})$ & MS & MS & MS & $\mathrm{ms}$ \\
\hline Fragaria vesca & $\mathrm{ms}$ & MS & $\mathrm{ms}$ & MS & MS & MS & MS \\
\hline Fragaria virginiana & $(\mathrm{ms})$ & MS & $\mathrm{ms}$ & MS & MS & (MS) & (ms) \\
\hline Galium triflorum & a & a & - & a & Is & LS & is \\
\hline Geranium viscosissimum & MS & MS & MS & MS & MS & MS & MS \\
\hline Hackelia micrantha & (MS) & $\mathrm{ms}$ & $\mathrm{ms}$ & $\mathrm{ms}$ & $\mathrm{ms}$ & a & a \\
\hline Iliamna rivularis & (ES) & $(E S)$ & (ES) & ES & es & ES & ES \\
\hline Lathyrus nevadensis & - & - & - & (c) & (C) & (C) & a \\
\hline Lupinus argenteus & - & - & - & - & - & - & - \\
\hline Lupinus caudatus & - & (LS) & - & (LS) & LS & a & a \\
\hline Lupinus sericeus & LS & (LS) & Is & (LS) & Is & a & $\mathbf{a}$ \\
\hline Penstemon attenuatus & MS & (MS) & (ms) & MS & $\mathrm{ms}$ & (MS) & $\mathrm{ms}$ \\
\hline Penstemon wilcoxii & (LS) & is & is & $\mathrm{ms}$ & $\mathrm{ms}$ & MS & MS \\
\hline Potentilla glandulosa & ES & ES & ES & ES & ES & ES & ES \\
\hline Pteridium aquilinum & $a$ & $a$ & - & $a$ & $a$ & $\mathrm{~ms}$ & $a$ \\
\hline Rudbeckia occidentalis & - & - & - & - & (ES) & (ES) & - \\
\hline Smilacina racemosa & c & c & (C) & c & C & c & c \\
\hline Thalictrum occidentale & (C) & (C) & (C) & (C) & (C) & (C) & c \\
\hline Veratrum californicum & (LS) & MS & a & MS & MS & MS & $\mathrm{ms}$ \\
\hline
\end{tabular}

\footnotetext{
${ }^{1} \mathrm{ES}=$ early seral; $\mathrm{a}=$ accidental; $\mathrm{MS}=$ mid seral; $($ ) = occurs in only part of the habitat type; $\mathrm{LS}=$ late seral; $\mathrm{C}=$ climax; upper case = major species occurrence; lower case = minor species occurrence.
} 
Table 13-Successional role of important herb layer species in major Douglas-fir habitat types of east-central Idaho.

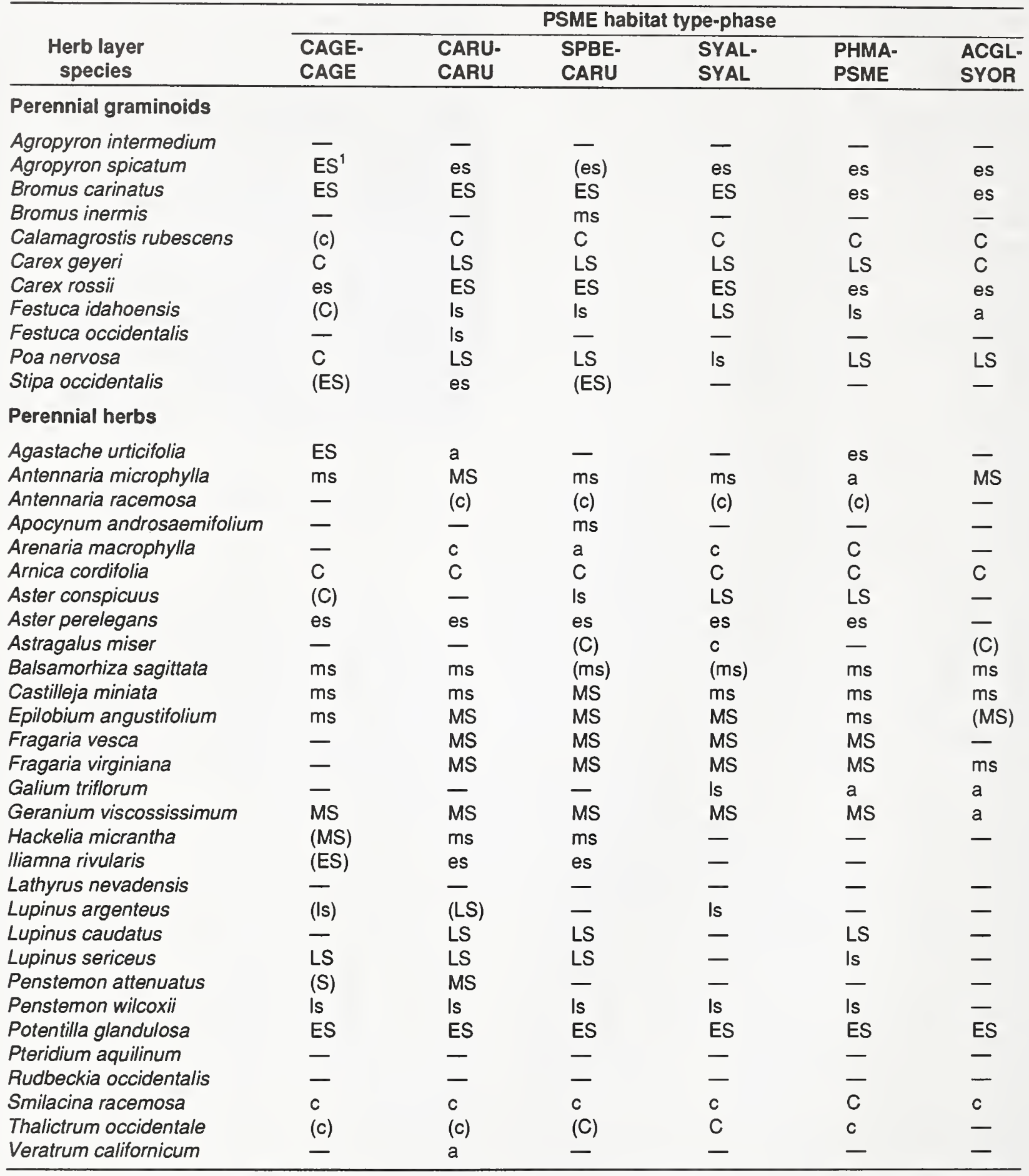

\footnotetext{
${ }^{1} E S=$ early seral; $a=$ accidental; MS = mid seral; ()$=$ occurs in only part of the habitat type; $L S=$ late seral; $C=$ climax; upper $\operatorname{cas} \theta=$ major species occurrence; lower $\operatorname{cas} \theta=$ minor species occurrence .
} 
Table 14-Successional strategies and disturbance responses of major herb layer species.

\begin{tabular}{|c|c|c|c|c|c|c|}
\hline \multirow[b]{2}{*}{$\begin{array}{l}\text { Herb layer } \\
\text { species }\end{array}$} & \multirow[b]{2}{*}{$\begin{array}{l}\text { Seed transport; } \\
\text { reproductlon methods }\end{array}$} & \multicolumn{5}{|c|}{ Type of disturbance ${ }^{\top}$} \\
\hline & & $\begin{array}{l}\text { CC, } \\
\text { NP }\end{array}$ & $\begin{array}{l}\text { SC, } \\
\text { MS }\end{array}$ & $\begin{array}{l}\text { CC, } \\
\text { MS }\end{array}$ & $\begin{array}{l}\mathrm{CC}, \\
\mathrm{BB}\end{array}$ & WF \\
\hline \multicolumn{7}{|l|}{ Perennial graminoids } \\
\hline Agropyron intermedium & $\begin{array}{l}\text { Wind, direct seeding; not stored in soil. Germinates } \\
\text { on bare soil in full sun. Generally rhizomatous. }\end{array}$ & $v^{2}$ & $\mathrm{D}$ & D-s & $s$ & $s$ \\
\hline Agropyron spicatum & $\begin{array}{l}\text { Wind; not stored in soil. Germinates on bare soil in } \\
\text { full sun. Generally nonrhizomatous. }\end{array}$ & $n$ & $D$ & D-s & s & s \\
\hline Bromus carinatus & $\begin{array}{l}\text { Wind; not stored in soil. Germinates on bare soil in } \\
\text { full sun. Nonrhizomatous. }\end{array}$ & $n$ & $\mathrm{D}$ & D-s & $\mathbf{s}$ & s \\
\hline Bromus inermis & $\begin{array}{l}\text { Wind, direct seeding; not stored in soil. Germinates on } \\
\text { bare soil in full sun. Increases by rhizomes. }\end{array}$ & v & $d$ & $d-s$ & V-s & V-s \\
\hline Calamagrostis rubescens & $\begin{array}{l}\text { Wind; not stored in soil. Germinates on bare soil. } \\
\text { Increases by rhizomes. }\end{array}$ & v & $d$ & $d$ & V-s & V-s \\
\hline Carex geyeri & $\begin{array}{l}\text { No obvious transport; stores in soil ( } 56 \text { percent viable). } \\
\text { Germinates on bare soil after burning or scarification. } \\
\text { Increases by short rhizomes. }\end{array}$ & $\mathrm{n}$ & D-S & D-S & s & $s$ \\
\hline Carex rossii & $\begin{array}{l}\text { No obvious transport; stores in soil ( } 51 \text { percent viable). } \\
\text { Germinates on bare soil mainly after scarification. } \\
\text { Nonrhizomatous. }\end{array}$ & $n$ & D-s & D-S & s & $s$ \\
\hline Festuca idahoensis & $\begin{array}{l}\text { Wind, not stored in soil. Germinates on bare soil. } \\
\text { Nonrhizomatous. }\end{array}$ & $n$ & D & D-s & s & $s$ \\
\hline Festuca occidentalis & $\begin{array}{l}\text { Wind; not stored in soil. Germinates on bare soil } \\
\text { in partial shade. Nonrhizomatous. }\end{array}$ & $\mathrm{n}$ & D-S & D-s & $n$ & $n$ \\
\hline Poa nervosa & $\begin{array}{l}\text { Wind; not stored in soil. Germinates on bare soil. } \\
\text { Increases by rhizomes. }\end{array}$ & v & $d-s$ & $d-s$ & $V-s$ & V-s \\
\hline Stipa occidentalis & $\begin{array}{l}\text { Wind; not stored in soil. Germinates on bare soil in } \\
\text { full sun. Nonrhizomatous. }\end{array}$ & $n$ & D & D-s & $s$ & s \\
\hline \multicolumn{7}{|l|}{ Perennial herbs and ferns } \\
\hline Agastache urticifolia & $\begin{array}{l}\text { No obvious transport; stored in soil ( } 67 \text { percent } \\
\text { viable). Germinates in bare soil in full sun mainly } \\
\text { after scarification. Nonrhizomatous. }\end{array}$ & $n$ & D & D-S & $s$ & s \\
\hline Antennaria microphylla & $\begin{array}{l}\text { Wind; not stored in soil. Germinates on bare soil in } \\
\text { full sun. Increases by stolons. }\end{array}$ & $\mathrm{n}$ & D & D-S & s & s \\
\hline Antennaria racemosa & $\begin{array}{l}\text { Wind; not stored in soil. Germinates in partial shade. } \\
\text { Increases by stolons. }\end{array}$ & $\mathrm{n}$ & D-s & D & d & d \\
\hline Apocynum androsaemifolium & $\begin{array}{l}\text { Wind; not stored in soil. Germination requirements } \\
\text { unknown. Increases by rhizomes. }\end{array}$ & V & $v$ & V & V & V \\
\hline Arenaria macrophylla & $\begin{array}{l}\text { No obvious transport; stores in soil ( } 20 \text { percent viable). } \\
\text { Germination requirements unknown. Increases by } \\
\text { rhizomes. }\end{array}$ & $n$ & D-s & D & $d$ & $d$ \\
\hline Arnica cordifolia & $\begin{array}{l}\text { Wind; not stored in soil. Germinates on bare soil } \\
\text { in partial shade. Increases by rhizomes. }\end{array}$ & $n$ & D-s & D & $\mathrm{n}$ & $n-s$ \\
\hline Aster conspicuus & $\begin{array}{l}\text { Wind; not stored in soil. Germinates on bare soil in } \\
\text { partial shade. Increases by rhizomes. }\end{array}$ & V & $d-s$ & $d$ & V & V-s \\
\hline Aster perelegans & Wind; not stored in soil. Germinates on bare soil in full sun. & n & D & D-s & s & s \\
\hline Astragalus miser & $\begin{array}{l}\text { No obvious transport; probably stores in soil. Germination } \\
\text { requirements unknown. Increases by rhizomes. }\end{array}$ & $n$ & D & $\mathrm{D}$ & d & $\begin{array}{c}d \\
\text { (con.) }\end{array}$ \\
\hline
\end{tabular}




\begin{tabular}{|c|c|c|c|c|c|c|}
\hline \multirow[b]{2}{*}{$\begin{array}{l}\text { Herb layer } \\
\text { species }\end{array}$} & \multirow[b]{2}{*}{$\begin{array}{l}\text { Seed transport; } \\
\text { reproduction methods }\end{array}$} & \multicolumn{5}{|c|}{ Type of disturbance } \\
\hline & & $\begin{array}{l}\mathrm{CC}, \\
\mathrm{NP}\end{array}$ & $\begin{array}{l}\text { SC, } \\
\text { MS }\end{array}$ & $\begin{array}{l}\text { CC, } \\
\text { MS }\end{array}$ & $\begin{array}{l}\mathrm{CC} \\
\mathrm{BB}\end{array}$ & WF \\
\hline Balsamorhiza sagittata & $\begin{array}{l}\text { Wind; not stored in soil. Germinates on bare } \\
\text { soil in full sun. }\end{array}$ & $n$ & $d$ & $d-S$ & $s$ & s \\
\hline Castilleja miniata & $\begin{array}{l}\text { Wind; storage ability unknown. Germinates } \\
\text { on mineral soil after scarification. }\end{array}$ & $v$ & $D$ & $D-s$ & $d$ & $d$ \\
\hline Epilobium angustifolium & $\begin{array}{l}\text { Wind; not stored in soil. Germinates on mineral soil } \\
\text { in full sun or partial shade. Increases by rhizomes. }\end{array}$ & v & $d-s$ & d-s & V-S & V-S \\
\hline Fragaria spp. & $\begin{array}{l}\text { Birds, mammals; stored in soil ( } 23 \text { percent viable). } \\
\text { Germinates on moist, bare soil in partial shade. } \\
\text { Increases by stolons. }\end{array}$ & v & D-s & $\mathrm{D}$ & $d$ & $d-s$ \\
\hline Galium triflorum & $\begin{array}{l}\text { Mammals; stored in soil ( } 62 \text { percent viable) } \\
\text { Germination requirements unknown. Increases } \\
\text { by rhizomes. }\end{array}$ & $d$ & $D$ & $\mathrm{D}$ & $\mathrm{D}$ & $\mathrm{D}$ \\
\hline Geranium viscosissimum & $\begin{array}{l}\text { No obvious transport; stores in soil ( } 90 \text { percent viable). } \\
\text { Germinates on bare soil in full sun. }\end{array}$ & $n$ & $d$ & d-S & s & $s$ \\
\hline Hackelia micrantha & $\begin{array}{l}\text { Mammals; storage capability unknown. } \\
\text { Germinates on bare soil in full sun. }\end{array}$ & $n$ & D & $D-s$ & $D$ & $\mathrm{D}$ \\
\hline Iliamna rivularis & $\begin{array}{l}\text { No obvious transport; stores in soil ( } 91 \text { percent viable). } \\
\text { Germinates on bare soil after burning. }\end{array}$ & $n$ & $\mathrm{D}$ & $D-s$ & D-S & D-S \\
\hline Lathyrus nevadensis & $\begin{array}{l}\text { No obvious transport; stores in soil ( } 100 \text { percent viable). } \\
\text { Germination requirements unknown. Increases by } \\
\text { rhizomes. }\end{array}$ & $v$ & $d$ & $d$ & $d$ & $d$ \\
\hline Lupinus spp. & $\begin{array}{l}\text { No obvious transport; stored in soil. Germination } \\
\text { requirements unknown. }\end{array}$ & $n$ & $v-s$ & v-s & $\mathbf{v}$ & $v$ \\
\hline Penstemon attenuatus & $\begin{array}{l}\text { No obvious transport, stored in soil. Germinates } \\
\text { on bare soil in full sun. }\end{array}$ & $n$ & $\mathrm{D}$ & D-S & $D-s$ & D-s \\
\hline Penstemon wilcoxii & $\begin{array}{l}\text { No obvious transport; stored in soil. Germinates on } \\
\text { bare soil in partial shade. }\end{array}$ & $n$ & D-S & D-s & D-s & D-s \\
\hline Potentilla glandulosa & $\begin{array}{l}\text { No obvious transport; stored in soil ( } 19 \text { percent viable). } \\
\text { Germinates on bare soil in full sun. }\end{array}$ & $n$ & $D-s$ & D-S & $v-s$ & $v-s$ \\
\hline Pteridium aquilinum & $\begin{array}{l}\text { Wind; not stored in soil. Germinates on bare sterile soil } \\
\text { in humid microsites. Increases aggressively by rhizomes. }\end{array}$ & v & V & V & V & V \\
\hline Rudbeckia occidentalis & $\begin{array}{l}\text { Wind; mammals?; not stored in soil. Germinates } \\
\text { on bare soil in full sun. }\end{array}$ & $v$ & $\mathrm{n}$ & $S$ & $v$-s & $v-s$ \\
\hline Smilacina racemosa & $\begin{array}{l}\text { Birds, mammals; not stored in soil. Germination } \\
\text { requirements unknown. }\end{array}$ & $\mathrm{n}$ & $D$ & $\mathrm{D}$ & $d$ & $n$ \\
\hline Thalictrum occidentale & $\begin{array}{l}\text { Mammals; not stored in soil. Germination requirements } \\
\text { unknown. Increases by rhizomes. }\end{array}$ & $n$ & $d$ & $\mathrm{D}$ & $\mathrm{D}$ & $\mathrm{D}$ \\
\hline Veratrum californicum & $\begin{array}{l}\text { Wind; storage capability unknown. Germination } \\
\text { requirements unknown. }\end{array}$ & $n$ & $\mathrm{D}$ & $\mathrm{D}$ & d & $\mathrm{n}$ \\
\hline
\end{tabular}

\footnotetext{
'Disturbance codes: CC, NP = clearcut, no site preparation; CC, MS = clearcut, mechanical scarification; SC, MS = shelterwood cut, mechanical scarification; CC, BB = clearcut, broadcast burned; WF = stand-destroying wildfire.

${ }^{2}$ Response codes: $V$ = vegetative increase from existing plants following tree removal (may be offset by treatment intensity); $S=$ seedling response (coverage increase depends on amount of viable seed available and may be influenced by treatment type and intensity); $D=$ decrease in existing canopy coverage; $n=$ no appreciable change; upper case letters = major change in species coverage; lower case letters = minor change in species coverage.
} 


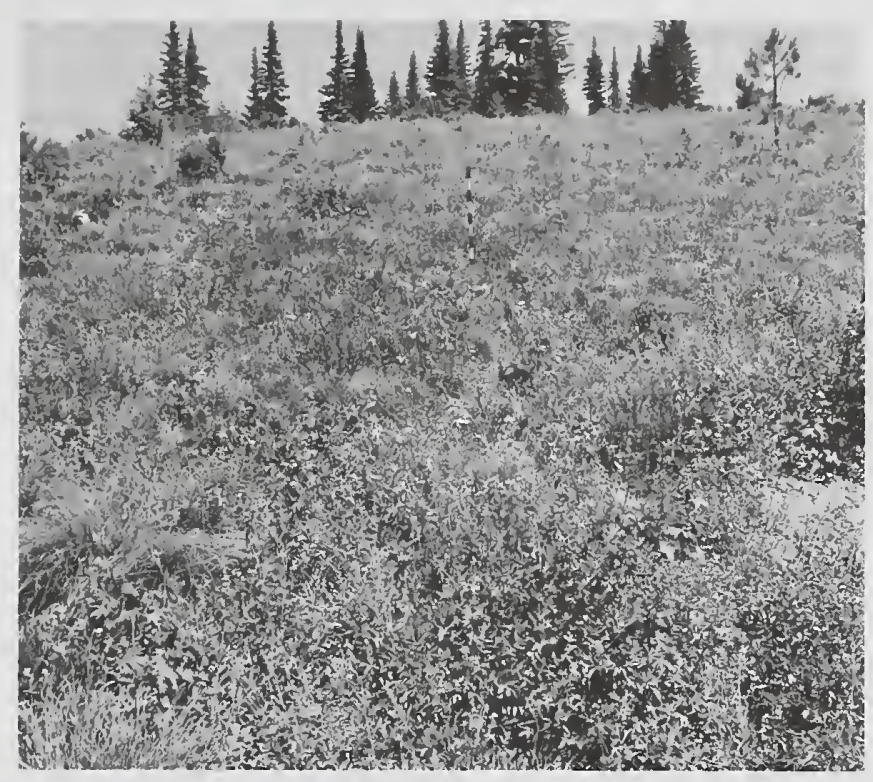

Figure 8-Elk sedge covers 85 percent of this Douglas-fir/elk sedge site. Only 5 percent of the ponderosa pine, planted in handscalps, have survived since the site was planted 13 years earlier.

to allelopathic effects of the coneflower (Ferguson 1991). The most difficult herb layer species to manage is bracken fern (Pteridium aquilinum). Bracken is a rhizomatous species capable of spreading up to $6 \mathrm{ft}(2 \mathrm{~m})$ per year (Buse 1992) and achieving nearly 60 percent canopy cover in 10 years after severe wildfire (fig. 9) (Stickney 1986). Fortunately, these growth rates only apply to sites much more favorable than the dry Douglas-fir habitat types of central Idaho. But bracken can be a problem for tree seedlings wherever it occurs. This fern is known to be allelopathic to small seedlings of certain conifers (del Moral and Cates 1971; Ferguson and Boyd 1988) and hardwoods (Horsely 1977). Dense bracken patches can exclude conifers for hundreds of years (Ferguson and Boyd 1988). Fortunately bracken is only moderately shade tolerant and will decline beneath a dense forest canopy. Bracken is also susceptible to certain herbicides, particularly glyphosate applied in late summer (Buse 1992; Conard and Emmingham 1984).

\section{Pocket Gophers}

Pocket gophers (Thomomys talpoides) have been a problem in pine plantations for half a century (Moore 1943). They are a normal component of most forest ecosystems but appear to increase their numbers to exceptionally high levels where some form of disturbance has stimulated the herb layer.

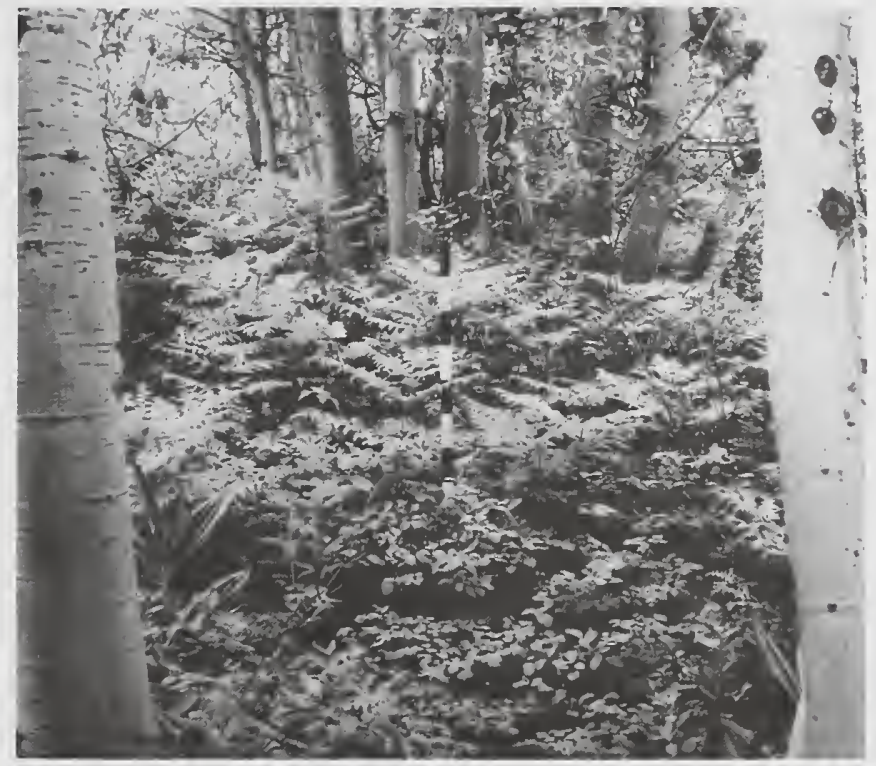

Figure 9-This Douglas-fir/common snowberry site experienced wildfire 52 years ago. The bracken fern, which probably established after the wildfire, has persisted in the stand.

Probably the most striking gopher increases occur in clearcuts although heavily grazed meadows can also support large gopher populations. In clearcuts, pocket gopher densities appear to be related to site treatment. Sites that were machine scarified and not burned support the most gopher activity (Steele and Geier-Hayes 1987, 1989a,b, 1993, 1994). However, in other geographic areas burning results in more gophers (Marsh and Steele 1992).

In west-central Idaho, machine scarification without burning tends to produce herb layers dominated by sticky cinquefoil (fig. 10). This plant is a preferred gopher forage species (Okello 1993). Other species preferred by pocket gophers during the summer include Achillea millefolium, Actaea rubra, Agastache urticifolia, Arnica cordifolia, Fragaria virginiana, Geranium viscosissimum, Iliamna rivularis, Lupinus sericeus, and Veratrum californicum (Okello 1993). All of these except Actaea occur in Douglas-fir habitat types. Most of these species increase following either severe burning or scarification. Nursery grown ponderosa pine seedlings were among the least preferred forage when tested against 28 common herb layer species (Okello 1993).

Most damage to pine seedlings occurs in winter (Marsh and Steele 1992). At that time, herb layer species are dormant and their roots may be in frozen soil; gopher tunnels are wet and may be flooded. Consequently, gophers, which may occur in large numbers due to an abundance of preferred herbaceous forage 


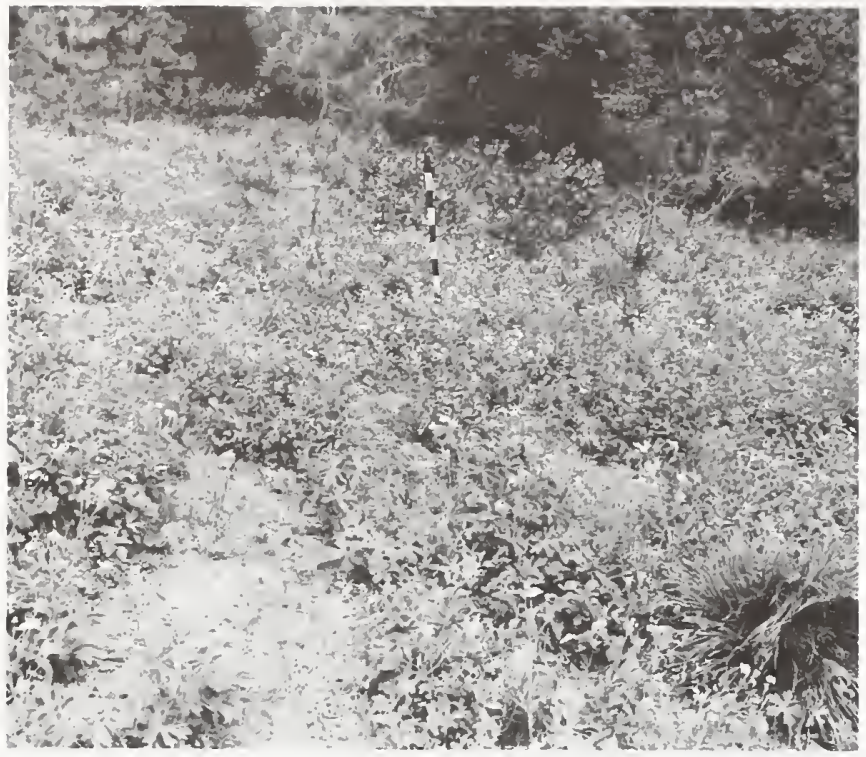

Figure 10-A Douglas-fir/white spirea habitat type, machine piled 17 years before. Potentilla glandulosa and Geranium viscosissimum dominate the forbs. Pocket gopher evidence occurs throughout the disturbed area.

during summer, tend to forage aboveground under the snow during winter. With most herbaceous material unavailable, shrub and tree seedlings come under concentrated attack. Maintaining small populations of preferred forage species through less disturbance and direct control of gophers through baiting appear to be the most effective approach to achieving small pocket gopher populations prior to tree planting. Once pine plantations are established, however, reducing preferred forage species can lead to increased damage of the pine seedlings (Boyd 1987) because there is little else for the gophers to eat. In pine plantations, direct control becomes the only feasible option to controlling gophers and must be continued for several years to be effective (Marsh and Steele 1992). However, direct control in plantations can be futile if adjacent areas support favorable habitat where the gophers can increase and then disperse into the plantations.

\section{Conclusions}

Disturbance initiates forest succession. Different vegetative communities result from different disturbance frequencies and intensities. Historically, fire was the predominant disturbance in Douglas-fir habitat types in central Idaho. The vegetative communities that resulted from historical fires evolved to produce sustainable and predictable ecosystems.
Some human-caused disturbances have created plant communities that are outside the historical range. Management problems including high gopher populations, poor tree seedling survival and growth, and inadequate natural regeneration appear associated with "abnormal" plant communities. Historic ecosystem processes can provide guidelines for management activities. Management practices that emulate natural systems appear to produce plant communities that regenerate faster and are less susceptible to insects and disease.

\section{References}

Amman, G. D.; Lessard, G. D.; Rasmussen, L. A.; O’Neil, C. G. 1988a. Lodgepole pine vigor, regeneration, and infestation by mountain pine beetle following partial cutting on the Shoshone National Forest, Wyoming. Res. Pap. INT-396. Ogden, UT: U.S. Department of Agriculture, Forest Service, Intermountain Research Station. 8 p.

Amman, G. D.; McGregor, M. D.; Schmitz, R. F.; Oakes, R. D. 1988b. Susceptibility of lodgepole pine to infestation by mountain pine beetles following partial cutting of stands. Canadian Journal of Forest Research. 18: 688-695.

Arno, S. F.; Gruell, G. E. 1983. Fire history at the forest-grassland ecotone in southwestern Montana. Journal of Range Management. 36(3): 332-336.

Arno, S. F.; Peterson, T. D. 1983. Variation in estimates of fire intervals: a closer look at fire history on the Bitterroot National Forest. Res. Pap. INT-301. Ogden, UT: U.S. Department of Agriculture, Forest Service, Intermountain Forest and Range Experiment Station. $8 \mathrm{p}$.

Barrett, D. K.; Usculpic, M. 1971. The field distribution of interacting strains of Polyporus schweinitzii and their origin. New Phytology. 70: 581-598.

Barrett, S. W. 1984. Fire history of the River of No Return Wilderness: River Breaks Zone. [Unpublished.] Missoula, MT: Systems for Environmental Management; 1984; Final Rep. 40 p.

Bartos, D. L.; Amman, G. D. 1989. Microclimate: an alternative to tree vigor as a basis for mountain pine beetle infestations. Res. Pap. INT-400. Ogden, UT: U.S. Department of Agriculture, Forest Service, Intermountain Research Station. 10 p.

Beecham, J. 1981. Black bear food preference ratings. Report on file at: U.S. Department of Agriculture, Forest Service, Intermountain Research Station, Boise, ID.

Binkley, D.; Cromack, K., Jr.; Fredriksen, R. L. 1982. Nitrogen accretion and availability in some snowbrush ecosystems. Forest Science. 28: 720-724. 
Boyd, R. J. 1987. Vegetation management and animal damage. In: Proceedings, animal damage management in Pacific Northwest forests; 1987 March 25-27; Spokane, WA. Pullman, WA: Washington State University: 55-58.

Boyd, R. J.; Miller, D. L.; Kidd, F. A.; Ritter, C. P. 1985. Herbicides for forest weed control in the northwest: a summary of effects on weeds and conifers. Gen. Tech. Rep. INT-195. Ogden, UT: U.S. Department of Agriculture, Forest Service, Intermountain Research Station. 66 p.

Bradley, A. 1984. Rhizome depth and potential fire survival of eight woody understory plants in Montana. Missoula, MT: University of Montana. $184 \mathrm{p}$. Thesis.

Buse, L. J. 1992. Critical silvics of bracken fern as related to vegetation management. Tech. Note TN-16. Thunder Bay, ON: Ontario Ministry of Natural Resources, Northwestern Ontario Forest Technology Development Unit. 8 p.

Byler, J. W. 1984. Status of disease pests in the interior Douglas-fir and grand fir types. In: Baumgartner, D. M.; Mitchell, R., eds. Silvicultural management strategies for pests of the interior Douglas-fir and grand fir types. 1984 February; Spokane, WA. Pullman, WA: Washington State University: 45-50. Cahill, D. 1978. Cutting strategies as control measures of the mountain pine beetle in lodgepole pine in Colorado. In: Berryman, A. A.; Amman, G. D.; Stark, R. W., tech. eds. Theory and practice of mountain pine beetle management in lodgepole pine forests. Symposium proceedings; 1978 April 25-27; Pullman, WA. Moscow, ID: University of Idaho, Forest, Wildlife, and Range Experiment Station: 188-191.

Cochran, P. H.; Barrett, J. W. 1993. Long-term response of planted ponderosa pine to thinning in Oregon's Blue Mountains. Western Journal of Applied Forestry. 8(4): 126-132.

Cochran, P. H.; Brock, T. 1985. Soil compaction and initial height growth of planted ponderosa pine. Res. Note PNW-434. Portland, OR: U.S. Department of Agriculture, Forest Service, Pacific Northwest Forest and Range Experiment Station. 4 p.

Conard, S. G.; Emmingham, W. H. 1984. Herbicides for brush and fern control on forest sites in western Oregon and Washington. Spec. Publ. 8. Corvallis, OR: Oregon State University, Forest Research Lab. $8 \mathrm{p}$.

Crane, M. F.; Fischer, W. C. 1986. Fire ecology of the forest habitat types of central Idaho. Gen. Tech. Rep. INT-218. Ogden, UT: U.S. Department of Agriculture, Forest Service, Intermountain Research Station. 86 p. del Moral, R.; Cates, R. G. 1971. Allelopathic potential of the dominant vegetation of western Washington. Ecology. 52: 1030-1037.

Ferguson, D. E. 1991. Allelopathic potential of western coneflower (Rudbeckia occidentalis). Canadian Journal of Botany. 69: 2806-2808.

Ferguson, D. E.; Boyd, R. J. 1988. Bracken fern inhibition of conifer regeneration in northern Idaho. Res. Pap. INT-388. Ogden, UT: U.S. Department of Agriculture, Forest Service, Intermountain Research Station. $11 \mathrm{p}$.

Froehlich, H. A. 1979. Soil compaction from logging equipment: effects on growth of young ponderosa pine. Journal of Soil and Water Conservation. 34: 276-278.

Froehlich, H. A.; Miles, D. W. R.; Robbins, R. W. 1985. Soil bulk density recovery on compacted skid trails in central Idaho. Soil Science Society of America Journal. 49: 1015-1017.

Furniss, M. M. 1962. Infestation patterns of Douglasfir beetle in standing and windblown trees in southern Idaho. Journal of Economic Entomology. 55: 486-491.

Furniss, M. M. 1965. Susceptibility of fire-injured Douglas-fir to bark beetle attack in southern Idaho. Journal of Forestry. 63: 8-11.

Furniss, M. M. 1979. An annotated bibliography of the Douglas-fir beetle (Dendroctonus pseudotsugae Hopkins). Gen. Tech. Rep. INT-48. Ogden, UT: U.S. Department of Agriculture, Forest Service, Intermountain Forest and Range Experiment Station. $40 \mathrm{p}$.

Graham, R. T.; Harvey, A. E.; Jurgensen, M. F. 1989. Effect of site preparation on survival and growth of Douglas-fir (Pseudotsuga menziesii Mirb. Franco.) seedlings. New Forests. 3: 89-98.

Gratkowski, H. J. 1962. Heat as a factor in germination of seeds of Ceanothus velutinus var. laevigatus T. and G. Corvallis, OR: Oregon State University. 122 p. Dissertation.

Hassel, W.; Carlson, J.; Doughty, J. 1983. Grasses for revegetation of mountain sites. In: Monsen, S. B.; Shaw, N., comps. Managing Intermountain rangelands-improvement of range and wildlife habitats. Proceedings of Symposia; 1981 September 15-17; Twin Falls, ID; 1982 June 22-24; Elko, NV. Gen. Tech. Rep. INT-157. Ogden, UT: U.S. Department of Agriculture, Forest Service, Intermountain Research Station: 95-101.

Helms, J. A.; Hipkin, C. 1986. Effects of soil compaction on height growth of a California ponderosa pine plantation. Western Journal of Applied Forestry. 1(4): 104-108. 
Horsely, S. B. 1977. Allelopathic inhibition of black cherry by fern, grass, goldenrod, and aster. Canadian Journal of Forest Research. 7: 205-519.

Jones, J. R.; DeByle, N. V. 1985. Fire. In: DeByle, N. V.; Winokur, R. P., eds. Aspen: ecology and management in the Western United States. Gen. Tech. Rep. RM-119. Fort Collins, CO: U.S. Department of Agriculture, Forest Service, Rocky Mountain Forest and Range Experiment Station: 77-81.

Kramer, N. B. 1984. Mature forest seed banks of three habitat types in central Idaho. Moscow, ID: University of Idaho. $107 \mathrm{p}$. Thesis.

Kufeld, R. C. 1973. Foods eaten by the Rocky Mountain elk. Journal of Range Management. 26: 106-113. Larson, M. M.; Schubert, G. H. 1969. Root competition between ponderosa pine and grass. Res. Pap. RM-54. Fort Collins, CO: U.S. Department of Agriculture, Forest Service, Rocky Mountain Forest and Range Experiment Station. 12 p.

Magnuson, J. J. 1990. Long-term ecological research and the invisible present. Bioscience. 40: 495-501.

Marsh, R. E.; Steele, R. W. 1992. Pocket gophers. In: Black, H. C., tech. ed. Silvicultural approaches to animal damage management in Pacific Northwest forests. Gen. Tech. Rep. PNW-GTR-287. Portland, OR: U.S. Department of Agriculture, Forest Service, Pacific Northwest Research Station: 205-230.

Martin, R. E. 1982. Fire history and its role in succession. In: Forest succession and stand development research in the Northwest: symposium proceedings; 1981 March 26; Corvallis, OR. Corvallis, OR: Oregon State University, Forest Research Laboratory: 92-99.

McDonald, P. M. 1986. Grasses in young conifer plantations - hindrance and help. Northwest Science. 60: 271-278.

McDonald, P. M.; Fiddler, G. O. 1989. Competing vegetation in ponderosa pine plantations: ecology and control. Gen. Tech. Rep. PSW-113. Berkeley, CA: U.S. Department of Agriculture, Forest Service, Pacific Southwest Forest and Range Experiment Station. 26 p.

McGregor, M. D.; Amman, G. D.; Schmitz, R. F.; Oakes, R. D. 1987. Partial cutting lodgepole pine stands to reduce losses to the mountain pine beetle. Canadian Journal of Forest Research. 17: 1234-1239.

McLean, A.; Clark, M. B. 1980. Grass, trees, and cattle on clearcut-logged areas. Journal of Range Management. 33: 213-217.

$\mathrm{McNabb}, \mathrm{K}$. 1991. Forestry herbicides are environmentally safe. Forest Farmer. 50(3): 16-18.

Minore, D. 1986. Effects of site preparation on seedling growth: a preliminary comparison of broadcast burning and pile burning. Res. Note PNW-452. Portland, OR: U.S. Department of Agriculture, Forest Service, Pacific Northwest Research Station. 12 p.
Minore, D.; Weatherly, W. G. 1990. Effects of site preparation on Douglas-fir seedling growth and survival. Western Journal of Applied Forestry. 5: 49-51.

Moore, A. W. 1943. The pocket gopher in relation to yellow pine reproduction. Journal of Mammalogy. 24(2): 271-273.

Morgan, P.; Aplet, G. H.; Haufler, J. B.; Humphries, H. C.; Moore, M. M.; Wilson, W. D. [In press.] Historical range of variability: a useful tool for evaluating ecosystem change. In: Sampson, R. N.; Adams, D. L., eds. Assessing forest health in the Inland West. Proceedings of American Forests Scientific Workshop; 1993 November 14-19; Sun Valley, ID. Binghamton, NY: Haworth Press.

Morris, L. A.; Pritchett, W. L.; Swindel, B. F. 1983. Displacement of nutrients into windrows during site preparation of a flatwood forest. Soil Science Society of America Journal. 47: 591-594.

Morrison, P. H.; Swanson, F. J. 1990. Fire history and pattern in a Cascade Range landscape. Gen. Tech. Rep. PNW-GTR-254. Portland, OR: U.S. Department of Agriculture, Forest Service, Pacific Northwest Research Station. 77 p.

Okello, M. M. 1993. Pocket gopher (Thomomys talpoides) food preferences, habitat relationships, and damage prevention. Moscow, ID: University of Idaho. $64 \mathrm{p}$. Thesis.

Oosting, H. J. 1956. The study of plant communities. San Francisco: W. H. Freeman and Co. 440 p. Petersen, T. D. 1988. Effects of interference from Calamagrostis rubescens on size distributions in stands of Pinus ponderosa. Journal of Applied Ecology. 25: 265-272.

Ross, D. W.; Scott, W.; Heninger, R. L.; Walstad, J. D. 1986. Effects of site preparation on ponderosa pine (Pinus ponderosa), associated vegetation, and soil properties in south central Oregon. Canadian Journal of Forest Research. 16: 612-618.

Ryan, K. C.; Frandsen, W. H. 1991. Basal injury from smoldering fires in mature Pinus ponderosa laws. International Journal of Wildland Fire. 1(2): 107-118.

Schmid, J. M.; Mata, S. A. 1992. Stand density and mountain pine beetle-caused tree mortality in ponderosa pine stands. Res. Note RM-515. Fort Collins, CO: U.S. Department of Agriculture, Forest Service, Rocky Mountain Forest and Range Experiment Station. $4 \mathrm{p}$.

Schmitz, R. F.; McGregor, M. D.; Amman, G. D.; Oakes, R. D. 1989. Effect of partial cutting treatments of lodgepole pine stands on the abundance and behavior of flying mountain pine beetles. Canadian Journal of Forest Research. 19: 566-574.

Schultz, A. M.; Launchbaugh, J. L.; Biswell, H. H. 1955. Relationship between grass density and brush seedling survival. Ecology. 36: 226-238. 
Sloan, J. P.; Ryker, R. A. 1986. Large scalps improve survival and growth of planted conifers in central Idaho. Res. Pap. INT-366. Ogden, UT: U.S. Department of Agriculture, Forest Service, Intermountain Research Station. 9 p.

Steele, R.; Arno, S. F.; Geier-Hayes, K. 1986. Wildfire patterns change in central Idaho's ponderosa pineDouglas-fir forest. Western Journal of Applied Forestry. 1: 16-18.

Steele, R.; Geier-Hayes, K. 1987. The Douglas-fir/elk sedge habitat type in central Idaho: succession and management. [Unpublished draft.] Boise, ID: U.S. Department of Agriculture, Forest Service, Intermountain Research Station. 111 p.

Steele, R.; Geier-Hayes, K. 1989a. The Douglas-fir/ ninebark habitat type in central Idaho: succession and management. Gen. Tech. Rep. INT-252. Ogden, UT: U.S. Department of Agriculture, Forest Service, Intermountain Research Station. $65 \mathrm{p}$.

Steele, R.; Geier-Hayes, K. 1989b. The Douglas-fir/ mountain maple habitat type in central Idaho: succession and management. [Unpublished draft.] Boise, ID: U.S. Department of Agriculture, Forest Service, Intermountain Research Station. 77 p.

Steele, R.; Geier-Hayes, K. 1993. The Douglas-fir/ pinegrass habitat type in central Idaho: succession and management. Gen. Tech. Rep. INT-298. Ogden, UT: U.S. Department of Agriculture, Forest Service, Intermountain Research Station. 83 p.

Steele, R.; Geier-Hayes, K. 1994. The Douglas-fir/ white spirea habitat type in central Idaho: succession and management. Gen. Tech. Rep. INT-305. Ogden, UT: U.S. Department of Agriculture, Forest Service, Intermountain Research Station. 81 p.

Steele, R.; Pfister, R. D.; Ryker, R. A.; Kittams, J. A. 1981. Forest habitat types of central Idaho. Gen. Tech. Rep. INT-114. Ogden, UT: U.S. Department of Agriculture, Forest Service, Intermountain Forest and Range Experiment Station. 138 p.
Stickney, P. F. 1986. First decade plant succession following the Sundance Forest Fire, northern Idaho. Gen. Tech. Rep. INT-197. Ogden, UT: U.S. Department of Agriculture, Forest Service, Intermountain Research Station. $26 \mathrm{p}$.

Thomas, J. W., tech. ed. 1979. Wildlife habitats in managed forests: the Blue Mountains of Oregon and Washington. Agric. Handb. 553. Washington, DC: U.S. Department of Agriculture, Forest Service. $512 \mathrm{p}$.

U.S. Department of Agriculture, Forest Service. 1986. Region 4-Range analysis handbook. On file at: U.S. Department of Agriculture, Forest Service, Intermountain Region, Ogden, UT.

Vander Wall, S. B. 1992. Establishment of Jeffrey pine seedlings from animal caches. Western Journal of Applied Forestry. 7(1): 14-20.

Wardle, D. A.; Parkinson, D. 1991. Relative importance of the effect of 2,4-D, glyphosate, and environmental variables on the soil microbial biomass. Plant and Soil. 134: 209-219.

Wellner, C. A. 1970. Fire history in the northern Rocky Mountains. In: The role of fire in the Intermountain West. Symposium proceedings; 1970 October 27-29; Missoula, MT. Missoula, MT: University of Montana, School of Forestry: 42-64.

Youngberg, C. T.; Wollum, A. G., II. 1976. Nitrogen accretion in developing Ceanothus velutinus stands. Soil Science Society of America Journal. 40: 109-112.

Younger, P. D.; Koch, R. G.; Kapustka, L. A. 1980. Allelochemic interference by quaking aspen leaf litter on selected herbaceous species. Forest Science. 26(3): 429-434.

Zavitkovski, J.; Newton, M. 1968. Ecological importance of snowbrush, (Ceanothus velutinus), in the Oregon Cascades. Ecology. 49: 1134-1145. 

Steele, Robert; Geier-Hayes, Kathleen. 1995. Major Douglas-fir habitat types of central Idaho: a summary of succession and management. Gen. Tech. Rep. INT-GTR-331. Ogden, UT: U.S. Department of Agriculture, Forest Service, Intermountain Research Station. 23 p.

This report summarizes important successional aspects of seven central Idaho Douglas-fir habitat types. The habitat types and phases are grouped geographically into west-central and east-central Idaho to differentiate site potential based on ponderosa pine occurrence. The role of fire and other management activities and their influence on common seral shrubs and herbs are discussed. Common seral tree species are included with discussions of natural and planted conifer regeneration and tree growth capability.

Keywords: forest succession, plant communities, forest ecology, forest management, silviculture, regeneration 


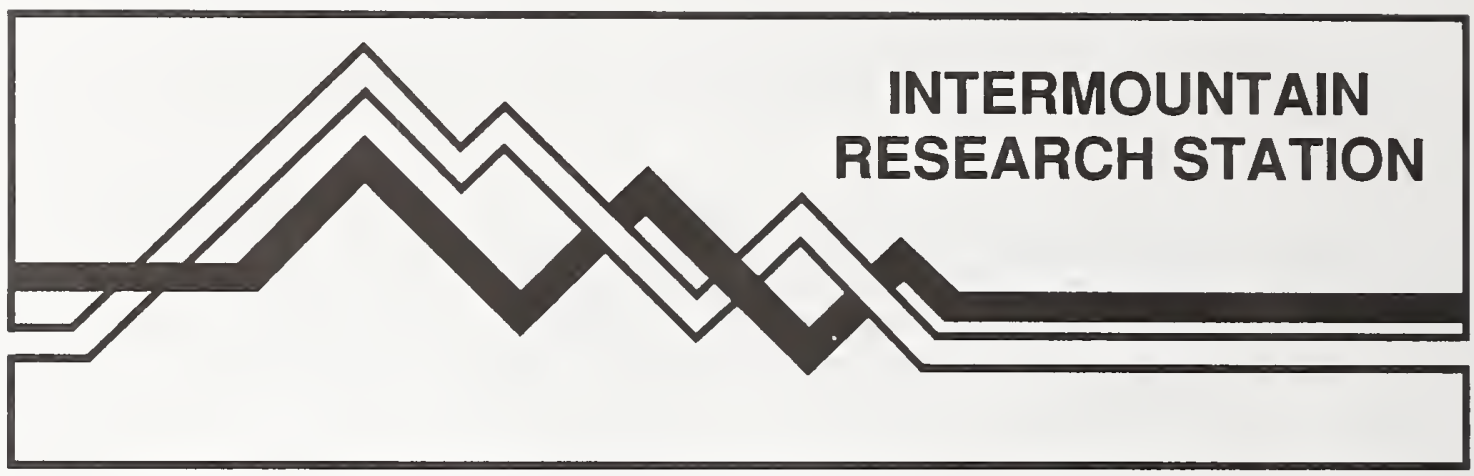

The Intermountain Research Station provides scientific knowledge and technology to improve management, protection, and use of the forests and rangelands of the Intermountain West. Research is designed to meet the needs of National Forest managers, Federal and State agencies, industry, academic institutions, public and private organizations, and individuals. Results of research are made available through publications, symposia, workshops, training sessions, and personal contacts.

The Intermountain Research Station territory includes Montana, Idaho, Utah, Nevada, and western Wyoming. Eighty-five percent of the lands in the Station area, about 231 million acres, are classified as forest or rangeland. They include grasslands, deserts, shrublands, alpine areas, and forests. They provide fiber for forest industries, minerals and fossil fuels for energy and industrial development, water for domestic and industrial consumption, forage for livestock and wildlife, and recreation opportunities for millions of visitors.

Several Station units conduct research in additional western States, or have missions that are national or international in scope.

Station laboratories are located in:

Boise, Idaho

Bozeman, Montana (in cooperation with Montana State University)

Logan, Utah (in cooperation with Utah State University)

Missoula, Montana (in cooperation with the University of Montana)

Moscow, Idaho (in cooperation with the University of Idaho)

Ogden, Utah

Provo, Utah (in cooperation with Brigham Young University)

Reno, Nevada (in cooperation with the University of Nevada)

The United States Department of Agriculture (USDA) prohibits discrimination in its programs on the basis of race, color, national origin, sex, religion, age, disability, political beliefs, and marital or familial status. (Not all prohibited bases apply to all programs.) Persons with disabilities who require alternative means of communication of program information (braille, large print, audiotape, etc.) should contact the USDA Office of Communications at (202) 720-2791.

To file a complaint, write the Secretary of Agriculture, U.S. Department of Agriculture, Washington, DC 20250, or call (202) 720-7327 (voice) or (202) 720-1127 (TDD). USDA is an equal employment opportunity employer. 